1 A novel portable filtration system for sampling and concentration of microorganisms: demonstration on 2 marine microalgae with subsequent quantification using IC-NASBA

4 Christos-Moritz Loukas ${ }^{\mathrm{a}, \mathrm{b}}$, Matthew C. Mowlem ${ }^{\mathrm{a}}$, Maria-Nefeli Tsaloglou ${ }^{\mathrm{a}, \mathrm{b}, \mathrm{c}}$ and Nicolas G. Green ${ }^{\mathrm{c}, \mathrm{d}}$ *

5

6 a. National Oceanography Centre (NOC), University of Southampton Waterfront Campus, European Way, 7 Southampton, $\mathrm{SO} 14 \mathrm{ZZH}$, United Kingdom.

b. Department of Ocean and Earth Science, University of Southampton Waterfront Campus, European Way, Southampton, SO14 3ZH, United Kingdom. 1BJ, United Kingdom.

d. School of Electronics and Computer Science (ECS), University of Southampton Highfield Campus, Highfield, Southampton, SO17 1BJ, United Kingdom.

* corresponding author

E-mail: ng2@ecs.soton.ac.uk

E-mail:cmloukas@gmail.com

E-mail: tsaloglou@gmwgroup.harvard.edu 


\section{Abstract}

This paper presents a novel portable sample filtration/concentration system, designed for use on samples of microorganisms with very low cell concentrations and large volumes, such as water-borne parasites, pathogens associated with fecal matter, or toxic phytoplankton. The example application used for demonstration was the in-field collection and concentration of microalgae from seawater samples. This type of organism is responsible for Harmful Algal Blooms (HABs), an example of which is commonly referred to as "red tides", which are typically the result of rapid proliferation and high biomass accumulation of harmful microalgal species in the water column or at the sea surface. For instance, Karenia brevis red tides are the cause of aquatic organism mortality and persistent blooms may cause widespread die-offs of populations of other organisms including vertebrates. In order to respond to, and adequately manage $\mathrm{HABs}$, monitoring of toxic microalgae is required and large-volume sample concentrators would be a useful tool for in situ monitoring of HABs. The filtering system presented in this work enables consistent sample collection and concentration from $1 \mathrm{~L}$ to $1 \mathrm{~mL}$ in five minutes, allowing for subsequent benchtop sample extraction and analysis using molecular methods such as NASBA and IC-NASBA. The microalga Tetraselmis suecica was successfully detected at concentrations ranging from $2 \times 10^{5}$ cells $/ \mathrm{L}$ to 20 cells $/ \mathrm{L}$. Karenia brevis was also detected and quantified at concentrations between $10 \mathrm{cells} / \mathrm{L}$ and $10^{6} \mathrm{cells} / \mathrm{L}$. Further analysis showed that the filter system, which concentrates cells from very large volumes with consequently more reliable sampling, produced samples that were more consistent than the independent non-filtered samples (benchtop controls), with a logarithmic dependency on increasing cell numbers. This filtering system provides simple, rapid, and consistent sample collection and concentration for further analysis, and could be applied to a wide range of different samples and target organisms in situations lacking laboratories.

\section{Keywords:}

Karenia Brevis

Tetraselmis Suecica

Filtering system

Concentrator

NASBA

Quantification 
61 LOC, Lab-on-a-Chip; HAB, Harmful algal blooms; IC-NASBA, nucleic acid sequence-based amplification with 62 internal control 


\section{Introduction}

Algal blooms are a natural worldwide phenomenon, resulting from rapid accumulation of algal populations in marine and freshwater systems. They form the basis of production in marine food webs and are often recognised from distinct water discoloration, caused by the pigments of associated algae (Davidson et al., 2011; Smythe-Wright et al., 2010). Some algal blooms have negative effects on humans, marine mammals, fish, and the overall marine ecosystem, with the harmful impact attributed either to high biomass or the production of biotoxins (Anderson et al., 2012; Anderson et al., 2002); the latter is of particular concern due to toxin accumulation in seafood, which can lead to human food poisoning. Consequently, Harmful Algal Blooms (HABs) have been well studied as they have a significant impact on the global economy and public health (Backer et al., 2015; Hoagland et al., 2002). In the United States alone, they annually affect expenses in public health ( $\$ 20$ million), commercial fisheries ( $\$ 18$ million) and recreational tourism ( $\$ 7$ million), while monitoring and management costs account for another $\$ 2$ million (Hoagland et al., 2002).

There are HAB-associated species in several phytoplankton groups, including diatoms, dictyochophyceae, dinoflagellates, haptophytes, raphidophyceae, and cyanobacteria. Dinoflagellates make up the majority of toxin producing microalgae and were even thought to be the only HAB species until the 1980s (Arff and Martin-Miguez, 2016). As of 2012, there have been 2,377 described dinoflagellate species, 80 of which are listed as toxin producers (Arff and Martin-Miguez, 2016; Gómez, 2012), and responsible for poisoning of marine life, animal mortalities and respirational conditions in humans (Ferrante et al., 2013; Fleming et al., 2011; Hallett et al., 2015; Pierce and Henry, 2008; Wang, 2008).

Thousands of fish and other species are killed annually by Karenia brevis (K. brevis) red tides alone, and persistent blooms may cause widespread die-offs of benthic communities and short-term declines in local fish populations (Landsberg et al., 2009). This toxic dinoflagellate is capable of having adverse effects on human health starting from concentrations as little as 5 cells $/ \mathrm{mL}$ (Bricelj et al., 2012) and is currently monitored by the Florida Fish and Wildlife Conservation Commission (FWRI, 2015) at concentrations between $10^{3}$ cells/L (bloom not present) and $10^{6}$ cells/L (bloom with high cell density). Even though there may be multiple causes of red tides, nutrients such as nitrates and phosphorus have an important role in sustaining microalgal blooms (Vargo et al., 2008). As a result, it is not surprising that areas of significant human induced pollution may lead to increased frequency of red tide outbreaks (Liu et al., 2013). Toxicity of HABs can be especially pronounced once phosphorous limitation occurs, as this has been suggested to be an important factor regulating cellular toxicity (Hardison et al., 2013). In order to adequately manage waste contamination and resulting HABs, particularly in regions of rapid economic and industrial growth, environmental monitoring is required.

Efficient sampling, sample analysis, and thus monitoring of HABs will help prevent direct or indirect damage to human health, as well as potentially significant financial losses for the fisheries and aquaculture industry. Importantly, it also serves as a means of identifying waste spills and contamination of the environment. 
Current methods for monitoring microalgal species using morphological assessment by microscopy or analogous techniques can be time-consuming, limiting the number of samples which can be analysed and the size of those samples. In addition, the acquired information may be limited regarding species-specific definition and toxin production. By contrast, molecular techniques, if automated, could accelerate the rate of sample analysis, while providing the benefits of increased accuracy and simultaneous examination of multiple parameters (Medlin, 2013).

This paper presents a novel filtration/concentration system, designed for the collection and concentration of seawater samples, which are characterised particularly by very low cell concentrations and therefore the requirement to process very large volumes. The system is intended primarily for manual, field sample processing of the sort required by environmental monitoring. Test samples were processed by the system and subsequently analysed using a molecular method for the detection and quantification of marine microorganisms. To demonstrate the viability of the method and to validate the operation and the detection capabilities of the system, two marine microorganisms were examined: Tetraselmis suecica (T. suecica), (Kylin) Butcher 1959 and K. brevis, (Davis) Hansen and Moestrup 2000.

\section{Background on Sample Collection and Molecular Tools for Environmental Analysis}

Field monitoring of ocean biology is typically done in the form of sample collection during organized cruises and sample analysis either on-board the research ship or in a laboratory at a later time. However, such research expeditions can be expensive, labour intensive and only cover a fraction of the oceans, since they follow pre-defined courses and locations. This leads to significant under-sampling and, consequently, alternative sampling or monitoring methods are used in an effort to fill the gaps. Remote sensing, for instance, is a cost-effective approach for estimating phytoplankton biomass, by determining chlorophyll concentration on satellite images (Blondeau-Patissier et al., 2014; Carvalho et al., 2010). Autonomous underwater vehicles implement in situ and deployable sensors for the analysis of biological samples, and may be useful for getting a more complete picture of ocean biology (Schofield et al., 2013). Microfluidic biosensors and lab-on-chip technologies will also play an important part in the future of ocean monitoring; this is particularly evident when looking at projects such as the European LABONFOIL and "The Ocean of Tomorrow" initiative, both funded by the European Commission, which invested in the development of microfluidic devices for the molecular sensing of phytoplankton, among others.

Molecular tools have been employed for the study of microbial diversity and ecology in natural environments since the mid-1980s (DeLong et al., 1989). Marine biology is an interdisciplinary study of life in the world's oceans, estuaries, and inland seas (Thakur et al., 2008) and it has witnessed significant growth in the application of molecular techniques. As a result, new fields of investigation have opened (Keeling et al., 2014), the distribution and composition of microbial populations has been re-defined (Valiadi et al., 2014), and in some cases, previous studies have been re-evaluated (Burton, 1996). Marine molecular biology is constantly evolving to solve problems regarding the exploration of marine organisms 
for human health and welfare purposes (Thakur et al., 2008). Genomics, transcriptomics, proteomics, and metabolomics have already provided information on phylogenetic relationships among HAB taxa, pathways of toxin production, $H A B$ diversity patterns, as well as genetic responses to grazers or inter- and intraspecies-specific competition (Anderson et al., 2012; Kohli et al., 2015).

One of the recent trends in this area, which has the potential to have a huge impact on environmental science in the future, is the use of technology to perform analysis in the field. Handheld analyzers for the detection of marine microorganisms in environmental samples, including $K$. brevis, have been investigated (Casper et al., 2007), as well as the application of biological sensors in the field of oceanography (Zehr et al., 2008). Microfluidic systems, both within and outside the field of oceanography, have been designed for numerous purposes such as molecule separation (Brody and Yager, 1997), genotyping (Rich et al., 2011) and for the performance of various biochemical and molecular assays (Lin et al., 2009). Also referred to as Lab-on-a-Chip (LOC), such systems have also been employed to monitor cell growth (Jeong et al., 2014; Lee et al., 2008), detect water-borne pathogens (Zhao et al., 2012), and observe a range cellular functions (Dimov et al., 2011) and behaviours associated with environmental toxicity (Huang et al., 2015; Zheng et al., 2014). Lab-on-a-Chip technologies provide the user with the benefits of miniaturisation, integration and automation. They therefore offer several advantages over conventional techniques: portability, speed of analysis, the ability to multiplex (Lutz et al., 2010), and platform and device compatibility with multiple molecular techniques (Loukas et al., 2017; Sun et al., 2013; Tsaloglou et al., 2013). When coupled with appropriate molecular tools, LOC devices may provide a greater understanding of the ecology and the evolution of $\mathrm{HAB}$ at species level and bloom dynamics.

Harmful algal blooms can be initiated by cells present at very low concentrations and some microorganisms, such as the toxic marine dinoflagellate $K$. brevis, are capable of having adverse effects on human health starting from concentrations as little as 5 cells $/ \mathrm{mL}$ (Bricelj et al., 2012). This is at odds with the volume of fluid typically analysed by LOC devices (typically a few microlitres). Reliable field detection of low cell concentrations with potential LOC-based detectors may therefore require robust collection methods, as well as pre-concentration of sample material.

Environmental sampling of phytoplankton may be achieved with a variety of sampling devices, typically mounted on ships and boats, but automated samplers can also be equipped on buoys, and autonomous under-water vehicles (Karlson et al., 2010). Collected microorganisms are often fixed and preserved with the use of chemicals such as Lugols iodine, aldehydes (Edler and Elbrächter, 2010), saline ethanol etc. or via freezing (Cembella and Rafuse, 2010). Sample concentration may then be achieved via filtering, sedimentation, or centrifugation. Autonomous samplers such as the Environmental Sample Processor (ESP), the IISA-Gene system, and the Autonomous Microbial Genosensor (AMG) have been developed and deployed for water sample collection and subsequent sample analysis. 
The ESP consists of a core sample processor, analytical and sampling modules, and uses custom designed reaction chambers to support a variety of filters and absorptive media, to allow for protocol adjustments. A rotating carousel, weighting $27 \mathrm{~kg}$, in conjunction with a robotic arm, two clamps, three syringe pumps, and a CCD camera, automate sample collection and then process samples under atmospheric pressure (Scholin et al., 2006). More recently, the ESP was redeveloped with a reinforced casing to conduct qPCR in the deep sea for in situ identification of aerobic methanotrophs (Ussler III et al., 2013), and was also used for qPCRbased detection of faecal indicators and harmful algae (Yamahara et al., 2015). The ESP has also been deployed for automated in situ sampling of heterotrophic bacteria and archaea, to perform whole-genome transcriptome profiling (Ottesen et al., 2014) and in relation to diurnal rhythm oscillations in terms of transcription, metabolic activity, and behavior. Evidently, this type of biological sampler provides significant flexibility with the integration of molecular assays, and allows for in situ analyses well below the ocean surface. However, the system is bulky, heavy, lacking portability and requiring a range of personnel to handle. The IISA-Gene system is an in situ biological analyzer capable of detecting gene fragments and analysing microbial activities in ocean environments (Fukuba et al., 2011a; Fukuba et al., 2011b). It uses a microfluidic device as its core element, whose components are immersed in fluorinated oil, to perform sample collection, along with nucleic acid extraction, and subsequent molecular analysis in an ambient environment. The microfluidic device is connected to a control unit, enclosed in a pressure vessel, and operated remotely using a personal computer. The IISA-Gene can be deployed at extreme depths and offers high assay adaptability, similar to the ESP system albeit more compact in size, and its most recent iteration can collect up to 128 samples simultaneously, but suffers from relatively small sample collection (0.5 mL per hour) (Okamura et al., 2013; Tsaloglou, 2016). The small sample collection process may affect the systems precision and could be particularly problematic for the detection of less abundant species.

The AMG is a microbiological sensing buoy, originally designed to perform nucleic acid sequence-based amplification (NASBA) for the detection of microbial water quality indicators (Fries and Paul, 2003; Fries et al., 2007). Samples are initially collected from ambient seawater with a syringe pump, and subsequently transferred to a rotating wheel that houses custom-made extraction columns, through a series of fluidic valves. Genetic material is filtered, extracted, and partially purified within the columns, with the help of motorised injectors, and finally transferred in a second rotation wheel connected to a reaction module. The AMG is battery-powered and capable of transmitting data via a WiFi connection, with the option to connect to a cabled network system for data transmission and power. The AMG offers superior portability when compared with systems akin to the ESP; however portability and sample pre-concentration is an area than can be further improved and simplified.

The aim of this study was to validate a novel filtration system which concentrates cells from several litres of sample into a single filter, while coupled with species-specific cell detection and quantification via NASBA analysis. This sampling method is designed to be simple, quick, and robust, without the need for additional chemical fixation of cells, or sample concentration steps. 


\section{Materials and Methods}

\subsection{Filter Concentrator}

The filter concentrator system was designed to improve field sampling for monitoring and acquired knowledge on the dynamics of phytoplankton populations, with requirements as follows. It should be capable of collecting large sample volumes, and condensing those samples to a volume manageable for molecular analysis, with a resulting concentration factor of several thousand. The user should be able to operate the system without the need for additional or otherwise specialized equipment, and without a source of electricity or other fuel source. The overall method should be able to accurately detect and quantify target species over a wide range of cell concentrations. K. brevis, for instance, should be detectable and quantifiable at concentrations between $10^{3}$ cells $/ \mathrm{L}$ (bloom not present) and $10^{6}$ cells $/ \mathrm{L}$ (bloom with high cell density); cell densities currently used for monitoring by the Florida Fish and Wildlife Conservation Commission (FWRI, 2015).

\subsubsection{Filter concentrator system}

The filter concentrator system is shown in Fig. 1 and consists of a portable filter/concentrator/pump formed from an adapted agricultural chemical spray backpack (Hozelock 12L Pressure Sprayer Plus: 4712) with a 12-litre sample capacity. The system passes the sample through a three stage filtering process: a plastic coarse ( $2 \mathrm{~mm}$ pore size) initial filter to trap large objects; a large area $\left(73.5 \mathrm{~cm}^{2}\right)$ second stage intermediate ( $40 \mu \mathrm{m}$ pore size) internal multi-use filter used to prevent large unwanted particles such as sand collecting in the sample filter; and a standard, commercially available, fine $(0.2 \mu \mathrm{m})$ CellTrap ${ }^{\text {TM }}$ CT40 (MEMTEQ Ventures Ltd, UK) collection filter. The multiuse filter was custom designed and manufactured from corrosion-resistant 316 stainless steel woven $40-\mu \mathrm{m}$ wire-cloth, soldered onto a 2-mm filter mesh (G. Bopp \& Co. Ltd.), to retain a robust barrel shape (Fig. 1). The filter was capped at one end with a stainless steel plate. The entirety of the system, including the complete pump assembly, trigger assembly, telescopic lance, and o-rings was made of biocompatible (Mast et al., 1997) propylene diene monomer (EPDM) rubber (see ESI document for further information).

The input of the sprayer was modified to hold the first two filters, with the collected sample (large volume - up to $10 \mathrm{~L}$ ) poured into the container through both filters and into the main body of the vessel. The output of the sprayer (at the end of the pump) was also modified to allow direct connection to the third filter - the CellTrap ${ }^{\mathrm{TM}}$ sample filter. This filter is designed for small-scale environmental sampling and targets sample volumes between $10 \mathrm{~mL}$ and $25 \mathrm{~L}$. The integrated hand pump is used to pump the pre filtered $(40 \mu \mathrm{m})$ sample through the CellTrap filter, which is intended to trap particles greater than the pore size $(0.2 \mu \mathrm{m})$. As a result, cells and other particles in the $0.2 \mu \mathrm{m}-40 \mu \mathrm{m}$ range are collected prior to extraction 
and processing. The CT40 filter has an approximate internal volume of $1 \mathrm{~mL}$, giving a maximum concentration factor of 10,000 .

\subsubsection{Filter test Procedure}

For each test run of a sample the filter system was initially rinsed with $70 \%$ ethanol, followed by thorough rinsing with reverse osmosis (RO) water. The filter system was then filled with five litres of artificial seawater spiked with target cells at varying concentrations. The $5 \mathrm{~L}$ samples were loaded by pouring into the vessel through the coarse filter as described above. $4 \mathrm{~L}$ of this sample was divided into four sub-samples by pumping $1 \mathrm{~L}$ successively through four different CellTrap ${ }^{\mathrm{TM}}$ collection filters. To account for initial variability caused by pressurising the hand pump and air being trapped and released in parts of the system, the first collection filter was discarded. The subsequent three were retained for analysis, giving three independent measurements for each sample.

To monitor pump performance, the flow rates were determined for every sub-sample during the operation of the filter concentrator. The filtrate was collected in a measuring cylinder and the time for every $100 \mathrm{~mL}$ increase in volume was recorded up to the maximum volume of $1 \mathrm{~L}$. The flow rate was then calculated for a granularity of $100 \mathrm{~mL}$ by dividing this volume by the difference in the recorded times.

\subsection{Sample composition and processing for analysis}

Tests were run with two different species for the purposes of determining limit of detection for the system and the accuracy of the concentration measurements. The filter samples were processed by extracting the cellular contents from the filter (including RNA) with $1 \mathrm{~mL}$ of chemical lysis buffer. The resulting lysate was then processed with a benchtop NASBA protocol. This section describes the two species, the production of the Internal Control RNA and the methods used for the extraction of cellular contents from the CellTrap ${ }^{\mathrm{TM}}$ collection filter and subsequent RNA extraction and purification.

\subsubsection{Culture Information}

To determine the limit of detection of the system, T. suecica strain MBA305 was employed as a model organism. The species was obtained from the Marine Biologica Association of the UK, and was originally collected from the Mediterranean, La Spezia as a non-axenic culture. The $T$. suecica strain was maintained in Erdschreiber medium, without shaking at $19 \pm 1{ }^{\circ} \mathrm{C}$ on a $12: 12$ hour light:dark cycle, under cool fluorescent light (85-95 $\mu \mathrm{mol}$ photons $\mathrm{m}^{-2} \mathrm{~s}^{-1}$; measured with a LI-189 light meter LI-COR ${ }^{\circledR}$, Lincoln, USA). Tests run with 
T. suecica were at concentrations of $2 \times 10^{5}$ cells $/ \mathrm{L}, 2 \times 10^{2}$ cells $/ \mathrm{L}$, and 20 cells $/ \mathrm{L}$, with the culture diluted to the required number of cells per litre by adding seawater.

To test the full analytical system (the filtration system coupled to IC-NASBA) and assess its ability to quantify HAB microalgae, $K$. brevis strain CCMP2228 was employed as a model organism. The species was obtained from the Provasoli-Guillard National Center for Culture of Marine Phytoplankton, and was originally isolated from the Gulf of Mexico, Sarasota Bay as a non-axenic culture. The $K$. brevis strain was maintained in L1 Aquil* medium, without shaking at $19 \pm 1{ }^{\circ} \mathrm{C}$ on a $12: 12$ hour light:dark cycle, under cool fluorescent light. Tests with $K$. brevis were conducted at concentrations of $10^{6} \mathrm{cells} / \mathrm{L}, 10^{5}$ cells $/ \mathrm{L}$, $10^{4}$ cells $/ L, 10^{3}$ cells $/ L$, and 10 cells $/ L$, with the culture diluted to the required number of cells per litre by adding seawater. NASBA was run with an internal control, as described below, to give quantitative measurements (Tsaloglou et al., 2013).

Independent non-filtered samples (controls) were run with a benchtop NASBA protocol, to evaluate the quantification efficiency of the system. The control samples were taken directly from the $K$. brevis culture and concentrated to a final volume of $1 \mathrm{~mL}$ via centrifugation. RNA extraction and benchtop NASBA took place in parallel with the Filtered samples.

\subsubsection{Internal Control (IC) RNA synthesis}

The Internal Control RNA employed for $K$. brevis experiments followed the same sequence as the wild-type RNA molecule of its $r b c L$ gene, with a length of $87 \mathrm{bp}$. The beacon binding site however was replaced with an enterovirus sequence, which could be recognised by a second molecular beacon within the NASBA assay. Synthesis of the IC RNA followed previously described protocols (Casper et al., 2005; Patterson et al., 2005; Tsaloglou et al., 2013). A DNA template (Eurofins MWG Operon, UK) was therefore designed containing a T3 RNA polymerase promoter at the 5' end of the sequence. The DNA template was employed for the transcription of IC RNA over the course of 2 hours at $37^{\circ} \mathrm{C}$, which was then purified (RNeasy kit, Qiagen, Netherlands) and quantified (Ribogreen RNA quantification kit, Invitrogen, UK) before storage at $20^{\circ} \mathrm{C}$ (Tsaloglou et al., 2013).

In order to validate and assess the effectiveness of the IC, serial dilutions of a $K$. brevis sample were prepared. NASBA with internal control (IC-NASBA), was then performed for test concentrations of $8 \times 10^{3}$, $10^{3}, 5 \times 10^{2}$, and 250 cells, along with a negative sample containing no cells.

\subsubsection{RNA extraction and NASBA ${ }^{\circledR}$ assays}


328

329

330

331

332

333

334

335

336

337

338

339

340

341

342

343

344

345

346

347

348

349

350

351

352

353

354

355

356

357

358

359

360

361

362

363

For T. suecica a commercial extraction kit (NucliSENS miniMAG ${ }^{\circledR}$, bioMérieux, UK) was used and the protocol supplied by the manufacturer was followed. For $K$. brevis the same process was used but with custom buffers. All chemicals were of highest purity and of molecular biology grade (Sigma-Aldrich, UK).

The first stage of extraction for filtered samples used a 1-mL syringe to elute the contents of the CellTrap ${ }^{\mathrm{TM}}$ filter. The syringe was preloaded with $0.2 \mathrm{~mL}$ of lysis buffer, which was then pushed into the filter and then extracted. Independent non-filtered control samples were taken directly from the $K$. brevis culture and concentrated to a final volume of $1 \mathrm{~mL}$. All samples were then placed into a tube containing an additional $1 \mathrm{~mL}$ of lysis buffer, giving a final volume of $1.2 \mathrm{~mL}$ for filtered samples and $2 \mathrm{~mL}$ for control samples. The lysis buffer for $T$. suecica was provided by the manufacturer and for $K$. brevis, Custom Buffer A was used (1\% Triton X-100, 4 M GuSCN, 0.5 M LiCl, 0.01 M EDTA, 0.1 M Tris, pH 7.5). For all $K$. brevis samples, $2.5 \mu \mathrm{L}$ of internal control (IC), containing 400 copies of IC RNA was then added.

Samples were incubated for ten minutes; $50 \mu \mathrm{L}$ of magnetic bead stock (bioMérieux UK Limited) was then added; followed by a further ten-minute incubation, to complete cell lysis. Mixing between each step was induced via vortexing.

All samples were then washed according to the following procedures. Samples were centrifuged and pipetting was used to remove and discard the supernatant solution. For washing of $T$. suecica, the manufacturers kit instructions were followed. For K. brevis, $500 \mu \mathrm{L}$ of Custom Buffer B was added to the remaining beads. Samples were then transferred to a NucliSENS ${ }^{\circledR}$ miniMAG $^{\circledR}$ and subject to magnetic attraction and mixing for thirty seconds. A subsequent $500 \mu \mathrm{L}$ of Buffer $\mathrm{B}$ was then used $(0.15 \mathrm{M} \mathrm{LiCl}, 1 \mathrm{mM}$ EDTA, $0.01 \mathrm{M}$ Tris, pH 7.5) to wash the beads a second time.

Finally, samples were eluted with the addition of $25 \mu \mathrm{L}$ of elution buffer (Buffer $\mathrm{C}$ in the case of $K$. brevis; $0.01 \mathrm{M}$ Tris, $\mathrm{pH} 7.5$ ), followed by shaking on an Eppendorf thermomixer at $60^{\circ} \mathrm{C}, 1200 \mathrm{rpm}$, for five minutes. Samples were then placed on a magnetic rack and the supernatant containing the RNA was removed. All extracted RNA samples were stored at $-20^{\circ} \mathrm{C}$ in preparation for NASBA ${ }^{\circledR}$ analysis.

The NucliSENS EasyQ ${ }^{\circledR}$ Basic Kit (bioMérieux UK Limited) was employed for all NASBA ${ }^{\circledR}$ assays, and according to manufacturer instructions. In the case of $T$. suecica, the reaction targeted the RuBisCO $r b c L$ gene and incorporated one set of forward/reverse primers, along with a molecular beacon (Table 1). Another set of primers was used to target the RuBisCO rbcL gene of $K$. brevis (Table 1). Two molecular beacons were integrated in the assay; one targeting $K$. brevis "wild-type" sequence and one targeting the IC (Tsaloglou et al., 2013). All primers and molecular beacons were obtained from Eurofins MWG Operon (London, UK). 
365

The molecular beacon targeting $T$. suecica was labelled with $\mathrm{CY} 5$ at the $5^{\prime}$ end and the quencher ECLIPSE at the $3^{\prime}$ end. The molecular beacon targeting $K$. brevis wild-type was labelled with Alexa Fluor 488 at the 5' end and the quencher BHQ1 at the $3^{\prime}$ end, whereas the IC molecular beacon was labelled with CY5 at the $5^{\prime}$ end and the quencher BHQ2 at the $3^{\prime}$ end.

\subsection{Quantification of RNA amount with NASBA ${ }^{\circledR}$ analysis method}

Analysis of NASBA reactions targeting $K$. brevis samples produced two fluorescence monitored reaction curves for each sample; one representing wild-type amplification and one representing IC amplification. Comparison of the two curves provides a method for determining the concentration of the target wild-type RNA.

Quantification of wild-type RNA, which serves as an indication of cell concentration, was initially attempted through time-to-positivity (TTP) ratios (Polstra et al., 2002). A threshold of detection (TOD) was set, and the point in time where each bi-exponential NASBA ${ }^{\circledR}$ curve rose above the TOD, was defined as a TTP value. The ratio of wild-type TTP and IC TTP was subsequently used as a quantitative indicator for the concentration in each sample.

A second, curve fitting method was also used for data analysis, by employing MATLAB ${ }^{\text {TM }}$ in conjunction with the following equation:

$$
Y(t)=\lambda Y_{0}-(\lambda-1) Y_{0} \exp \left\{-1 / 2 k_{1} a_{1}\left[\ln \left(1+e^{a_{2}\left(t-a_{3}\right)}\right)\right]^{2}\right\}
$$

This equation describes NASBA-driven RNA amplification, where $Y(t)$ the fluorescence signal as a function of time, Y0 the signal at $t=0, \lambda Y_{0}$ the fluorescence value at its highest point, $\alpha_{1} \alpha_{2}$ representing the shape of the curve, $\alpha_{3}$ defining the curve location relative to the time axis, and $k_{1}$ a reaction rate constant (Weusten et al., 2002). Each curve fit results in a set of parameters whose values represent the appropriate NASBA curve. Every IC-NASBA reaction produces two curves (one for the WT-RNA and one for the IC-RNA) and two sets of parameters. The quantitation variable is then determined by calculating the $k_{1} a_{1} a_{2}^{2}$ ratio from the parameters for the WT and IC curves. This method produces a quantitative metric for the concentration of WT RNA in the original sample.

In this work, the MATLAB ${ }^{\text {TM }}$ curve-fitting tool was used to produce a quantitation variable, defined as the $k_{1} a_{1} a_{2}^{2}$ ratio, which is linearly related to the logarithm of the amount of wild-type RNA in a sample and is an indicator of target cell concentration (Tsaloglou et al., 2011). 


\section{Results}

\subsection{Filtering System Operation}

Data describing the flow through the filtering system are illustrated in Fig. 2. The results are shown as cumulative volume against cumulative time demonstrating the main linear period of operation followed by the slower period approaching one litre as the operator reduced pressure (Fig. 2A). The same data is also plotted as average volumetric flow rate, determined for each $100 \mathrm{~mL}$ sub-sample, against cumulative volume (Fig. 2B). The results provide evidence of constant flow rate at approximately $5 \mathrm{~mL} / \mathrm{s}$ for the first two thirds of the operating period, with an increase near the beginning; this is due to variable charging of the volume of fluid contained within the barrel of the hand pump. Moreover, as the hand pump is usercontrolled and inherently variable, significant flow rate variation was observed between runs ( $28 \%$ at $200 \mathrm{~mL}$ processed volume) whereas anticipation of the point at which $1 \mathrm{~L}$ of sample is processed led to the significant reduction (up to $300 \%$ ) of flow rate after 200 seconds and $700 \mathrm{~mL}$. This end point is related only to the discharge of pressure: in tests where $5 \mathrm{~L}$ were processed, the flow rate remained constant until $300 \mathrm{~mL}$ before end of pumping.

\subsection{Initial measurements: Tetraselmis suecica}

Runs using NASBA were performed on filtered $T$. suecica samples at different concentrations and produced three distinct curves (Fig. 3). Amplification for the $2 \times 10^{5}$ cells/L concentration samples was observed from thirteen minutes, reaching 29.08 relative fluorescence units (RFUs) at the peak of the reaction. The 200 cells/L concentration samples showed amplification from nineteen minutes and peaked at 27.65 RFUs. Samples from the 20 cells/L concentration amplified after twenty-minutes, and reached a maximum fluorescence of 22.80 RFUs. Standard deviation between samples increased as cell concentration decreased, and highest standard deviation values were observed for the 20 cells/L samples (6.52). The error bars show the standard deviation of each data point.

4.3 Quantitative measurement of Karenia brevis

\subsubsection{Initial measurements and verification of method}

Runs using IC-NASBA were performed on serial dilutions of a $K$. brevis laboratory sample and a standard curve was produced as shown in Fig. 4. This illustrates the relationship between the value of $\operatorname{In}$ (Qvariable 
ratio) and log10(number of cells). Note that data points represent single replicates, and not triplicate samples. The results showed a clear trend, closely following a linear function with an $\mathrm{R}^{2}$ value of 0.997 . This demonstrated the effectiveness of the Internal Control and the curve-fitting method of quantitation, allowing for the subsequent detection and quantification of $K$. brevis.

\subsubsection{Filter results}

A range of concentrations of $K$. brevis samples were filtered and NASBA was performed successfully. The ESI document contains the complete set of data on the results of NASBA, as well as the matching parameters derived from the curve fitting, an example of which is shown in Fig. 5 for the $10^{5}$ cells/L sample.

The comparative trends in the curves of the IC (at fixed concentration) and wild-type changed as the wildtype cell concentrations changed. The increase in fluorescence above threshold used in the standard NASBA analysis method is an indicator of concentration. Wild-type curves at $10^{6}$ cells $/ \mathrm{L}$ experienced an increase in fluorescence at approximately nine minutes before IC curves; at $10^{4}$ cells $/ \mathrm{L}$ amplification occurred at the same time; for lower concentrations, the wild-type signal increase occurred after IC in all cases. The overall wild-type signal was at its lowest for the 10 cells/L samples and never surpassed 0.42 RFUs. The independent non-filtered control samples followed a similar trend.

Looking more closely at the results, using the example in Fig. 5, it is apparent that the difference in gradient of the rising section of the curve between the WT-RNA and the IC-RNA for the amplification signals is greater for the control samples than for the filtered samples. In addition, the filtered replicates show IC amplification approximately seven minutes after WT amplification, and IC maximum fluorescence is reached 15-20 minutes after the WT equivalent. By comparison, the corresponding times for the control samples are less than five minutes, and 10-15 minutes.

The data calculated from the whole data set with TTP ratios and quantitation variable ratios plotted against increasing cell concentration for (a) filtered samples and (b) non-filtered control samples is shown in Fig 6 . The fitting parameters are summarised in Table 2. For both sets of samples the trendlines fitted to the TTP ratio data had similar intercept and slope values but with an R-squared value of $99.8 \%$ for the filtered samples and $83.4 \%$ for the control samples. The fitting for the quantitation variable ratio data showed more variability and less agreement between the fit parameters, with an R-square value of $98.3 \%$ for the filtered samples and $87.4 \%$ for the control samples.

\section{Discussion}


The basic flow rate measurements demonstrated that the hand-powered pump in the filtering system produced an approximately constant flow rate throughout the testing period and was capable of processing $1 \mathrm{~L}$ of sample in five minutes. The use of the CT40 CellTrap ${ }^{\mathrm{TM}}$ filter as the output stage in the filtering experiments enabled sample concentrations of 1000:1 to be achieved. The system, therefore, performed a rapid and consistent sample collection, suitable for operator in field environmental testing.

\subsection{Limit of detection: Tetraselmis suecica}

The microalga $T$. suecica was successfully detected at all concentrations, ranging from $2 \times 10^{5}$ cells $/ \mathrm{L}$ to 20 cells/L. The shape of the NASBA curves, show a discernible trend with varying concentration: that of a steeper rising curve coupled with a shorter time to positivity (TTP) as cell numbers increased. These initial results demonstrate that the filter concentrator system can be considered for quantitative measurements, down to a concentration of 20 cells/L.

\subsection{Analysis and quantification of Karenia brevis}

The results indicate that there is a relationship between wild-type and IC curves which is dependent on $K$. brevis concentration in both filtered samples and corresponding independent non-filtered control samples. In order to demonstrate the quantification properties of the filtering system, the NASBA results were analysed using the TTP and quantitation variable ratios. Following the example sample (Fig. 5), the calculated values indicate that at $10^{5}$ cells, the non-filtered control method extracted a higher amount of $K$. brevis RNA, with an average quantitation variable value of 2.04. By comparison, the filtered equivalent was 1.05.

The results summarised in Fig. 6 and Table 2 indicate that samples processed by the filter concentrator system produced a more consistent linear trend with logarithmic cell number than the independent nonfiltered controls. The fit to the trend is marginally better using the TTP ratio data rather than the quantitation variable for quantification, and significantly better for the filtered samples compared to the independent non-filtered control samples. Overall, this suggests that RNA quantification using the filter system would be more accurate. However, the results from the filter system show slightly increased variability (decreased precision) vs the control. This is more pronounced at low concentrations and in the results using the quantification variable. This variability arises from the fact that the samples have a large volume with very low cell numbers, compounded by needing to recover small cell numbers at the elution stage. This can be mitigated by increasing the number of replicates and/or increasing the volume sampled for low cell concentrations to increase the number of cells. 
The results from the two analysis methods lead to several conclusions. The filter concentrator demonstrated the measurement of cell concentration, with the TTP analysis providing a better quantification of this than the quantitation variable method. The independent non-filtered control samples in these experiments did not provide the same accuracy. The two different methods also provide different calculations of variability with the TTP ratio values having smaller standard deviations at lower concentrations than the quantitation variable method, with the conclusion that the first method provides a more accurate determination of the concentration of small cell numbers in these experiments. Based on the successful repeated measurement of samples at a concentration of $10 \mathrm{cells} / \mathrm{L}$, the limit of detection can be estimated as approximately three times the smallest measured concentration or 30 cells/L, well below the detection limit required for early detection of bloom formation.

The filter processes litres of sample prior to analysis, which reduces the inaccuracy associated with sampling small numbers. Independent non-filtered control samples, by comparison, involved the handling of significantly smaller volumes (a few $\mathrm{mL}$ at a time) thus increasing the chances and degree of sampling error. More importantly, the error experienced in the control samples would have been enough to misjudge target cell concentration by one or two orders of magnitude. These data support the need for large-volume sample concentrators within the field of phytoplankton and HAB studies, for more accurate and precise monitoring and estimation of bloom formation.

For the operation of the filter contractor system, at higher cell concentrations factors such as increased compaction, large differential pressures, or high levels of RNA, all could affect the quality of cell extraction and lysis. An effective mitigation strategy would then be to filter smaller volumes when cell concentrations reach $10^{5}$ cells/L. To improve consistency in calculated values for cell concentrations below $10^{2}$ cells $/ \mathrm{L}$, the solution would simply be to filter larger volumes of sample.

\section{Conclusions}

This paper presents a novel filter-concentrator system, designed for the collection and concentration of seawater samples, characterised particularly by very low cell concentrations and the requirements of processing large volumes for manual sample processing in the field. The filtering system was capable of maintaining an approximately constant flow, with a rapid and consistent sample collection at $1 \mathrm{~L}$ in five minutes. The microalga $T$. suecica was successfully detected at all filtered concentrations, ranging from $2 \times 10^{5}$ cells/L to 20 cells/L. Initial IC-NASBA results showed correlation with $K$. brevis concentration in filtered samples. Further analysis showed that samples derived from the filter system more accurately followed a linear trend versus logarithmic cell number than the independent non-filtered controls. When compared to standard benchtop analysis, the filtering system improved accuracy of $K$. brevis quantification via IC-NASBA (higher $\mathrm{R}^{2}$ value), but a small decrease in precision was observed (higher standard deviation values). The presented sampling method successfully quantified $K$. brevis across all concentration ranges used by the Florida Fish and Wildlife Conservation Commission for bloom monitoring. This included 
545 concentrations of 10 cells/L which is two orders of magnitude below the minimum of what is recognised as 546 a bloom (1000 cells/L) (FWRI, 2015) and could permit detection and measurement of populations in a pre547 bloom state.

549 This filter-concentrator system provides simple, rapid, and consistent sample collection and concentration, 550 and could become a useful tool for in-field monitoring of HABs, water-borne parasites, and pathogens 551 associated with faecal matter. Additional research will be required to further optimise extraction methods. 552 Coupling of the system with other molecular analysis methods would demonstrate flexibility regarding its 553 application. Finally, using it in conjunction with Lab-on-a-Chip devices, to analyze environmental samples, 554 could prove to be a viable and powerful tool for on-field monitoring of HABs and human pollution.

555

\section{Acknowledgements}

557

558 The authors would like to acknowledge funding support by the Natural Environment Research Council, the 559 University of Southampton and EUFP7 LABONFOIL project 224306.

560 


\section{References}

Anderson, D.M., Cembella, A.D., Hallegraeff, G.M., 2012. Progress in understanding harmful algal blooms: Paradigm shifts and new technologies for research, monitoring, and management. Annual Review of Marine Science 4(1), 143-176.

Anderson, D.M., Glibert, P.M., Burkholder, J.M., 2002. Harmful algal blooms and eutrophication: Nutrient sources, composition, and consequences. Estuaries 25(4), 704-726.

Arff, J., Martin-Miguez, B., 2016. Marine microalgae and harmful algal blooms: A European perspective, In: Tsaloglou, M.-N. (Ed.), Microaglae: Current Research and Applications. Caister Academic Press.

Backer, L.C., Manassaram-Baptiste, D., LePrell, R., Bolton, B., 2015. Cyanobacteria and algae blooms: Review of health and environmental data from the Harmful Algal Bloom-Related Illness Surveillance System (HABISS) 2007-2011. Toxins 7(4), $1048-1064$.

Blondeau-Patissier, D., Gower, J.F.R., Dekker, A.G., Phinn, S.R., Brando, V.E., 2014. A review of ocean color remote sensing methods and statistical techniques for the detection, mapping and analysis of phytoplankton blooms in coastal and open oceans. Progress In Oceanography $123,123-144$.

Bricelj, V.M., Haubois, A.G., Sengco, M.R., Pierce, R.H., Culter, J.K., Anderson, D.M., 2012. Trophic transfer of brevetoxins to the benthic macrofaunal community during a bloom of the harmful dinoflagellate Karenia brevis in Sarasota Bay, Florida. Harmful Algae 16(0), 27-34.

Brody, J.P., Yager, P., 1997. Diffusion-based extraction in a microfabricated device. Sensors and Actuators A: Physical 58(1), 13-18.

Burton, R.S., 1996. Molecular tools in marine ecology. Journal of Experimental Marine Biology and Ecology 200(1-2), 85-101.

Carvalho, G.A., Minnett, P.J., Fleming, L.E., Banzon, V.F., Baringer, W., 2010. Satellite remote sensing of harmful algal blooms: A new multi-algorithm method for detecting the Florida red tide (Karenia brevis). Harmful Algae 9(5), 440-448.

Casper, E.T., Patterson, S.S., Bhanushali, P., Farmer, A., Smith, M., Fries, D.P., Paul, J.H., 2007. A handheld NASBA analyzer for the field detection and quantification of Karenia brevis. Harmful Algae 6(1), 112-118.

Casper, E.T., Patterson, S.S., Smith, M.C., Paul, J.H., 2005. Development and evaluation of a method to detect and quantify enteroviruses using NASBA and internal control RNA (IC-NASBA). Journal of Virological Methods 124(1-2), 149-155.

Cembella, A.D., Rafuse, C., 2010. Chapter 7 The filter-transfer-freeze method for quantitative phytoplankton analysis, Microscopic and Molecular Methods for Quantitative Phytoplankton Analysis. Intergovernmental Oceanographic Commission UNESCO, pp. 41-46.

Davidson, K., Tett, P., Gowen, R., 2011. Chapter 4 Harmful Algal Blooms, Marine Pollution and Human Health. The Royal Society of Chemistry, pp. 95-127.

DeLong, E.F., Wickham, G.S., Pace, N.R., 1989. Phylogenetic stains: Ribosomal RNA-based probes for the identification of single cells. Science 243(4896), 1360-1363.

Dimov, I.K., Kijanka, G., Park, Y., Ducree, J., Kang, T., Lee, L.P., 2011. Integrated microfluidic array plate (iMAP) for cellular and molecular analysis. Lab on a Chip 11(16), 2701-2710.

Edler, L., Elbrächter, M., 2010. Chapter 2 The Utermöhl method for quantitative phytoplankton analysis, Microscopic and Molecular Methods for Quantitative Phytoplankton Analysis. Intergovernmental Oceanographic Commission UNESCO, pp. 13-20.

Ferrante, M., Conti, G.O., Fiore, M., Rapisarda, V., Ledda, C., 2013. Harmful algal blooms in the Mediterranean Sea: Effects on human health. EuroMediterranean Biomedical Journal 8(6), 25-34.

Fleming, L.E., Kirkpatrick, B., Backer, L.C., Walsh, C.J., Nierenberg, K., Clark, J., Reich, A., Hollenbeck, J., Benson, J., Cheng, Y.S., Naar, J., Pierce, R., Bourdelais, A.J., Abraham, W.M., Kirkpatrick, G., Zaias, J., Wanner, A., Mendes, E., Shalat, S., Hoagland, P., Stephan, W., Bean, J., Watkins, S., Clarke, T., Byrne, M., Baden, D.G., 2011. Review of Florida red tide and human health effects. Harmful Algae 10(2), 224-233. 
Fries, D., Paul, J., 2003. Autonomous Microbial Genosensor. DTIC Document.

Fries, D., Paul, J., Smith, M., Farmer, A., Casper, E., Wilson, J., 2007. The autonomous microbial genosensor, an in situ sensor for marine microbe detection. Microscopy and Microanalysis 13(S02), 514-515.

Fukuba, T., Aoki, Y., Fukuzawa, N., Yamamoto, T., Kyo, M., Fujii, T., 2011a. A microfluidic in situ analyzer for ATP quantification in ocean environments. Lab on a Chip, 3508-3515.

Fukuba, T., Miyaji, A., Okamoto, T., Yamamoto, T., Kaneda, S., Fujii, T., 2011b. Integrated in situ genetic analyzer for microbiology in extreme environments. RSC Advances 1(8), 1567-1573.

FWRI, 2015. Red Tide Current Status, Florida Fish and Wildlife Conservation Commission.

Gómez, F., 2012. A checklist and classification of living dinoflagellates (Dinoflagellata, Alveolata). Cicimar Oceánides 27(1), 65-140.

Hallett, C.S., Valesini, F.J., Clarke, K.R., Hoeksema, S.D., 2015. Effects of a harmful algal bloom on the community ecology, movements and spatial distributions of fishes in a microtidal estuary. Hydrobiologia, 1-18.

Hardison, D.R., Sunda, W.G., Shea, D., Litaker, W.R., 2013. Increased toxicity of Karenia brevis during phosphate limited growth: Ecological and evolutionary implications. PLoS ONE 8(3), e58545.

Hoagland, P., Anderson, D.M., Kaoru, Y., White, A.W., 2002. The economic effects of harmful algal blooms in the United States: Estimates, assessment issues, and information needs. Estuaries 25(4), 819-837.

Huang, Y., Aldasoro, C.C.R., Persoone, G., Wlodkowic, D., 2015. Integrated microfluidic technology for sub-lethal and behavioral marine ecotoxicity biotests, SPIE Microtechnologies. International Society for Optics and Photonics, pp. 95180F-95180F-95110.

Jeong, H.-H., Jeong, S.-G., Park, A., Jang, S.-C., Hong, S.G., Lee, C.-S., 2014. Effect of temperature on biofilm formation by Antarctic marine bacteria in a microfluidic device. Analytical Biochemistry 446, 90-95.

Karlson, B., Godhe, A., Cusack, C., Bresnan, E., 2010. Chapter 1 Introduction to methods for quantitative phytoplankton analysis, Microscopic and Molecular Methods for Quantitative Phytoplankton Analysis. Intergovernmental Oceanographic Commission UNESCO, pp. 5-12.

Keeling, P.J., Burki, F., Wilcox, H.M., Allam, B., Allen, E.E., Amaral-Zettler, L.A., Armbrust, E.V., Archibald, J.M., Bharti, A.K., Bell, C.J., 2014. The Marine Microbial Eukaryote Transcriptome Sequencing Project (MMETSP): Illuminating the functional diversity of eukaryotic life in the oceans through transcriptome sequencing. PLoS Biology 12(6), e1001889.

Kohli, G.S., John, U., Figueroa, R.I., Rhodes, L.L., Harwood, D.T., Groth, M., Bolch, C.J.S., Murray, S.A., 2015. Polyketide synthesis genes associated with toxin production in two species of Gambierdiscus (Dinophyceae). BMC Genomics 16(1), 410.

Landsberg, J.H., Flewelling, L.J., Naar, J., 2009. Karenia brevis red tides, brevetoxins in the food web, and impacts on natural resources: Decadal advancements. Harmful Algae 8(4), 598-607.

Lee, J.-H., Kaplan, J., Lee, W., 2008. Microfluidic devices for studying growth and detachment of Staphylococcus epidermidis biofilms. Biomedical Microdevices 10(4), 489-498.

Lin, Z., Cherng-Wen, T., Roy, P., Trau, D., 2009. In-situ measurement of cellular microenvironments in a microfluidic device. Lab on a Chip 9(2), 257-262.

Liu, L., Zhou, J., Zheng, B., Cai, W., Lin, K., Tang, J., 2013. Temporal and spatial distribution of red tide outbreaks in the Yangtze River Estuary and adjacent waters, China. Marine Pollution Bulletin 72(1), 213-221.

Loukas, C.-M., McQuillan, J.S., Laouenan, F., Tsaloglou, M.-N., Ruano-Lopez, J.M., Mowlem, M.C., 2017. Detection and quantification of the toxic microalgae Karenia brevis using lab on a chip mRNA sequence-based amplification. Journal of Microbiological Methods 139, 189-195. 
Lutz, S., Weber, P., Focke, M., Faltin, B., Hoffmann, J., Muller, C., Mark, D., Roth, G., Munday, P., Armes, N., Piepenburg, O., Zengerle, R., von Stetten, F., 2010. Microfluidic lab-on-a-foil for nucleic acid analysis based on isothermal recombinase polymerase amplification (RPA). Lab on a Chip 10(7), 887-893.

Mast, F., Hoschtitzky, J.A.R.D., Van Blittersqijl, C.A., Huysmans, H.A., 1997. In vitro biocompatibility of EPM and EPDM rubbers. Journal of Materials Science: Materials in Medicine 8(1), 5-9.

Medlin, L., 2013. Molecular tools for monitoring harmful algal blooms. Environmental Science and Pollution Research 20(10), 66836685.

Okamura, K., Noguchi, T., Hatta, M., Sunamura, M., Suzue, T., Kimoto, H., Fukuba, T., Fujii, T., 2013. Development of a 128-channel multi-water-sampling system for underwater platforms and its application to chemical and biological monitoring. Methods in Oceanography 8, 75-90.

Ottesen, E.A., Young, C.R., Gifford, S.M., Eppley, J.M., Marin, R., Schuster, S.C., Scholin, C.A., DeLong, E.F., 2014. Multispecies diel transcriptional oscillations in open ocean heterotrophic bacterial assemblages. Science 345(6193), 207-212.

Patterson, S.S., Casper, E.T., Garcia-Rubio, L., Smith, M.C., Paul lii, J.H., 2005. Increased precision of microbial RNA quantification using NASBA with an internal control. Journal of Microbiological Methods 60(3), 343-352.

Pierce, R.H., Henry, M., 2008. Harmful algal toxins of the Florida red tide (Karenia brevis): Natural chemical stressors in South Florida coastal ecosystems. Ecotoxicology 17(7), 623-631.

Polstra, A., Goudsmit, J., Cornelissen, M., 2002. Development of real-time NASBA assays with molecular beacon detection to quantify mRNA coding for HHV-8 lytic and latent genes. BMC Infectious Diseases 2(1), 18.

Rich, V.I., Pham, V.D., Eppley, J., Shi, Y., DeLong, E.F., 2011. Time-series analyses of Monterey Bay coastal microbial picoplankton using a 'genome proxy' microarray. Environmental Microbiology 13(1), 116-134.

Schofield, O., Glenn, S., Moline, M., 2013. The robot ocean network. American Scientist 101(6), 434-441.

Scholin, C., Jensen, S., Roman, B., Massion, E., Marin, R., Preston, C., Greenfield, D., Jones, W., Wheeler, K., 2006. The Environmental Sample Processor (ESP) - an autonomous robotic device for detecting microorganisms remotely using molecular probe technology, OCEANS 2006, pp. 1-4.

Smythe-Wright, D., Boswell, S., Kim, Y.-N., Kemp, A., 2010. Spatio-temporal changes in the distribution of phytopigments and phytoplanktonic groups at the Porcupine Abyssal Plain (PAP) site. Deep Sea Research Part II: Topical Studies in Oceanography 57(15), 1324-1335.

Sun, Y., Hogberg, J., Christine, T., Florian, L., Monsalve, L.G., Rodriguez, S., Cao, C., Wolff, A., Ruano-Lopez, J.M., Bang, D.D., 2013. Pre-storage of gelified reagents in a lab-on-a-foil system for rapid nucleic acid analysis. Lab on a Chip 13(8), 1509-1514.

Thakur, N.L., Jain, R., Natalio, F., Hamer, B., Thakur, A.N., Müller, W.E.G., 2008. Marine molecular biology: An emerging field of biological sciences. Biotechnology Advances 26(3), 233-245.

Tsaloglou, M.-N., 2016. Microfluidics and in situ sensors for microalgae, In: Tsaloglou, M.-N. (Ed.), Microaglae: Current Research and Applications. Caister Academic Press, pp. 133-151.

Tsaloglou, M.-N., Bahi, M.M., Waugh, E.M., Morgan, H., Mowlem, M., 2011. On-chip real-time nucleic acid sequence-based amplification for RNA detection and amplification. Analytical Methods 3(9), 2127-2133.

Tsaloglou, M.-N., Laouenan, F., Loukas, C.-M., Monsalve, L.G., Thanner, C., Morgan, H., Ruano-López, J.M., Mowlem, M.C., 2013. Real-time isothermal RNA amplification of toxic marine microalgae using preserved reagents on an integrated microfluidic platform. Analyst 138(2), 593-602.

Ussler III, W., Preston, C., Tavormina, P., Pargett, D., Jensen, S., Roman, B., Marin III, R., Shah, S.R., Girguis, P.R., Birch, J.M., 2013. Autonomous application of quantitative PCR in the deep sea: In situ surveys of aerobic methanotrophs using the deep-sea environmental sample processor. Environmental Science and Technology 47(16), 9339-9346. 
681 Valiadi, M., Painter, S.C., Allen, J.T., Balch, W.M., Iglesias-Rodriguez, M.D., 2014. Molecular detection of bioluminescent 682 dinoflagellates in surface waters of the Patagonian Shelf during early austral summer 2008. PLoS ONE 9(6), e98849.

683 Vargo, G.A., Heil, C.A., Fanning, K.A., Dixon, L.K., Neely, M.B., Lester, K., Ault, D., Murasko, S., Havens, J., Walsh, J., Bell, S., 2008. 684 Nutrient availability in support of Karenia brevis blooms on the central West Florida Shelf: What keeps Karenia blooming. 685 Continental Shelf Research 28(1), 73-98.

686 Wang, D.-Z., 2008. Neurotoxins from marine dinoflagellates: A brief review. Marine Drugs 6(2), 349-371.

687 Weusten, J.J.A.M., Carpay, W.M., Oosterlaken, T.A.M., van Zuijlen, M.C.A., van de Wiel, P.A., 2002. Principles of quantitation of viral 688 loads using nucleic acid sequence-based amplification in combination with homogeneous detection using molecular beacons. 689 Nucleic Acids Research 30(6), e26.

690 Yamahara, K.M., Demir-Hilton, E., Preston, C.M., Marin, R., Pargett, D., Roman, B., Jensen, S., Birch, J.M., Boehm, A.B., Scholin, C.A., 691 2015. Simultaneous monitoring of faecal indicators and harmful algae using an in-situ autonomous sensor. Letters in Applied 692 Microbiology 61(2), 130-138.

693 Zehr, J.P., Hewson, I., Moisander, P.H., 2008. Molecular biology techniques and applications for ocean sensing. Ocean Science 5(2), 694 101-113.

695 Zhao, X., Dong, T., Yang, Z., Pires, N., Hoivik, N., 2012. Compatible immuno-NASBA LOC device for quantitative detection of 696 waterborne pathogens: Design and validation. Lab on a Chip 12(3), 602-612.

697 Zheng, G.-x., Li, Y.-j., Qi, L.-I., Liu, X.-m., Wang, H., Yu, S.-p., Wang, Y.-h., 2014. Marine phytoplankton motility sensor integrated into 698 a microfluidic chip for high-throughput pollutant toxicity assessment. Marine Pollution Bulletin 84(1), 147-154. 
Fig. 1 Schematic diagram of the internal structure of the filter/concentrator pump system, constructed from a Hozelock ${ }^{\mathrm{TM}}$ chemical spray backpack and consisting of a plastic fluid vessel which contains the filters and a hand operated pressure pump on opposite sides. Samples are processed through three stages of filtering, concurrent with a high degree of sample concentration. The first stage is a $2 \mu \mathrm{m}$ pore size plastic pre-filter to catch large floating objects. The second stage is a $40 \mu \mathrm{m}$ pore size 316 stainless steel woven wire-cloth main filter with a height of $26 \mathrm{~cm}$ and diameter of $9 \mathrm{~cm}$, with a filtering surface area of $73.5 \times 10^{3} \mathrm{~mm}^{2}$. These two stages perform the initial filtering of the sample as it is poured into the vessel prior to pumping, and retains particles larger in size than $40 \mu \mathrm{m}$, with the large surface area ensuring minimal clogging. The hand pump is then used to push the filtered sample through the third stage filter, the Celltrap ${ }^{\mathrm{TM}}$ CT40 $0.2 \mu \mathrm{m}$ filter, attached to the output of the pump. The complete system is configured to retain material between 0.2 and $40 \mu \mathrm{m}$, passing up to 10 litres of sample through the final stage filter, simultaneously reducing the sample volume to $1 \mathrm{~mL}$.

Fig 2. Volumetric flow rate through the filter system. Data are averages of nineteen runs at varying cell concentration with the error bars representing standard deviation, A: Graph of cumulative volume passed through the filtering system against cumulative time taken and B: Graph of volumetric flow rate against cumulative volume. The pump runs consistently at a rate of approximately $4.6 \mathrm{~mL} / \mathrm{sec}$, with a small rise and fall at the start of pumping as the hand pump is pressurised, followed by a consistent flow rate until the end of the required volume where the flow rate tapers off as the hand pump pressure is allowed to fall off.

Fig 3. NASBA results for $T$. suecica. The $y$-axis represents relative fluorescence units, as measured by the EasyQ benchtop incubator, and the $x$-axis represents time in minutes. WT-RNA amplification of 20 cells equivalents is shown as red squares, 200 cells are shown as blue circles, $2 \times 10^{5}$ cells are shown as green triangles, and the negative control (zero cells) is shown as purple reverse triangle. Error bars denote one standard deviation of triplicate samples.

Fig 4. Standard Curve showing how the quantitation variable ratio changes with cell number (round circles). Also shown is a fitted trendline to the data, with the fitting equation and the R2 value shown. The graph is plotted with $\log 10$ of the number of cells so that the fitted equation has a simple representation.

Fig 5. IC-NASBA results for $10^{5}$ cell equivalents of $K$. brevis with 400 IC copies. The $\neg y$-axis represents relative fluorescence units, as measured by the Easy $Q$ benchtop incubator, and the $x$-axis represents time in minutes. WT-RNA amplification is shown as red squares and IC-RNA amplification is shown as green circles. Control samples are illustrated on the left whereas filtered samples are shown on the right. Error bars denote one standard deviation of triplicate samples.

Fig 6. Quantitation analysis on IC-NASBA results, using TTP analysis method (top row) and Quantitation variable analysis method (bottom row), for $A$ : the filtered samples and $B$ : the control samples. TTP ratios 
738 and $\ln \left(\mathrm{k}_{1} \mathrm{a}_{1} \mathrm{a}_{2}{ }^{2}\right.$ ratios) were plotted over increasing cell concentration (log scale). Control samples are 739 represented by red circles and filtered samples are represented by blue squares. Error bars denote one 740 standard deviation of triplicate samples. Also shown are the lines of best fit and the shaded area 741 represents the $95 \%$ confidence bands.

742

743 Table 1. List of the sequences of $T$. suecica primers, beacons, and RNA (designed for the purpose of this 744 study); the sequences of $K$. brevis and Internal Control (IC) primers, beacons, and RNA modified from 745 (Tsaloglou et al., 2013). Bold underlined text indicates primer binding sites.

747 Table 2. List of curve matching parameters from the analysis presented in Fig 6 . In each case, the matching 748 parameters are based on the linear equation $y=c+m * x$. 


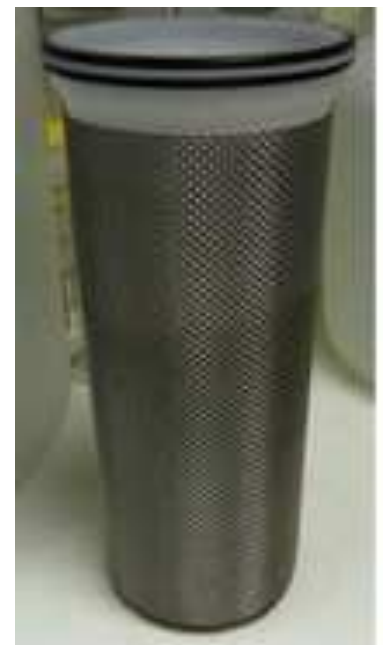

1-12 litres of sample, filtered to $40 \mu \mathrm{m}$ prior to pumping action

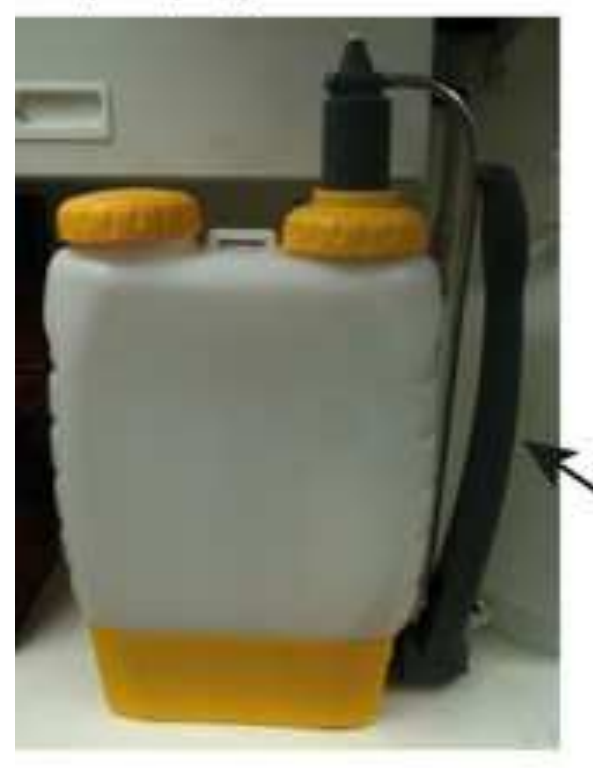

Sample poured through first two filters before pumping.
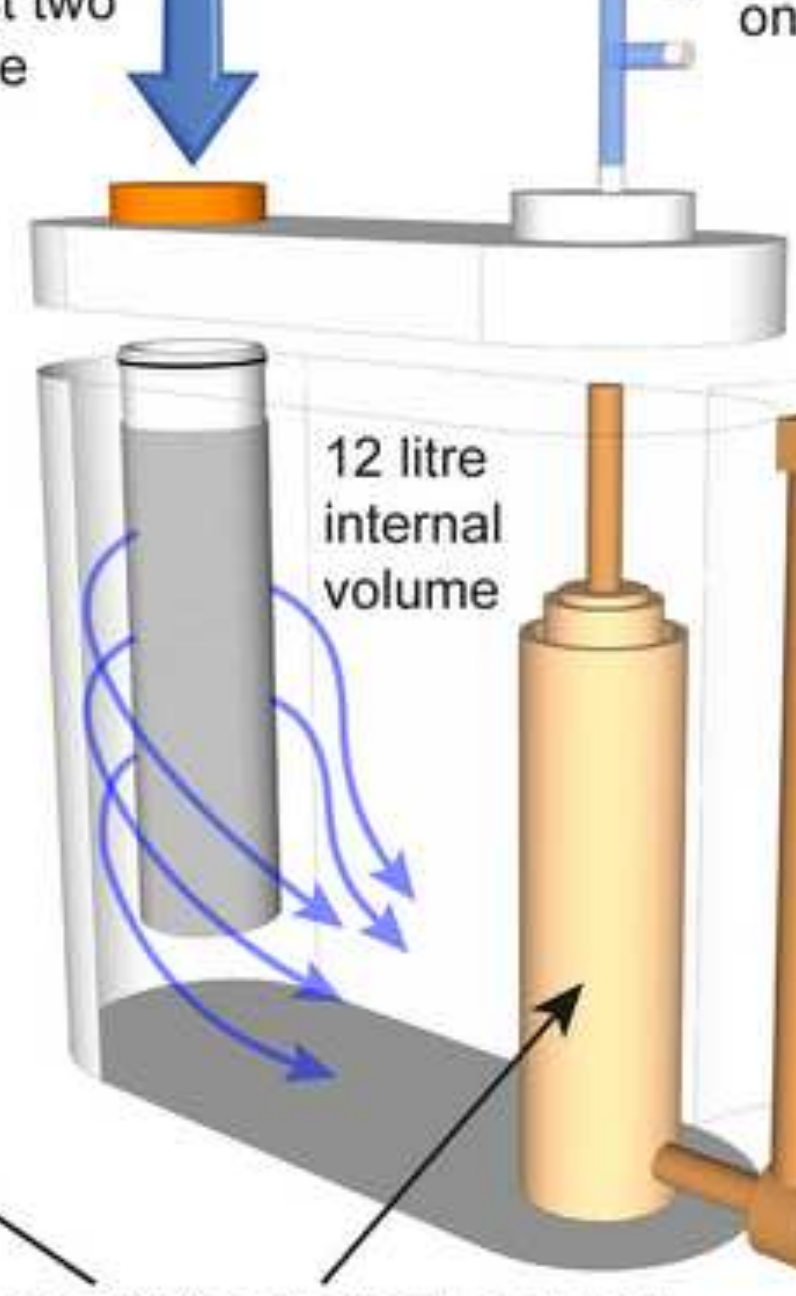

Pump: Self contained, isolated from sample chamber by valve

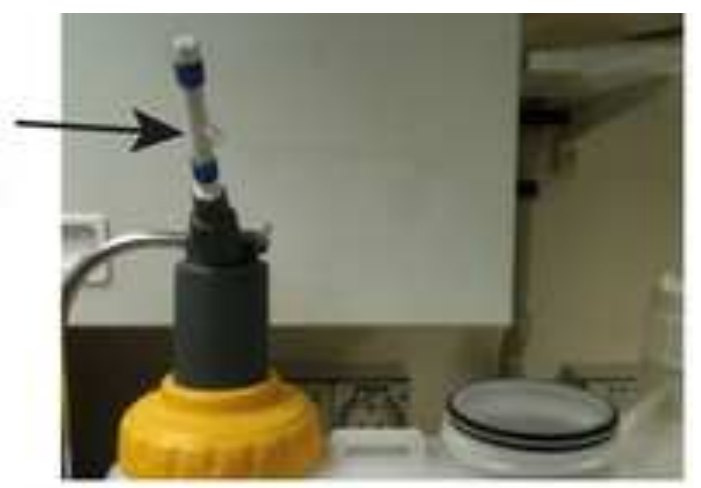

Readily replaceable $200 \mathrm{~nm}$ final stage trapping filter for cells

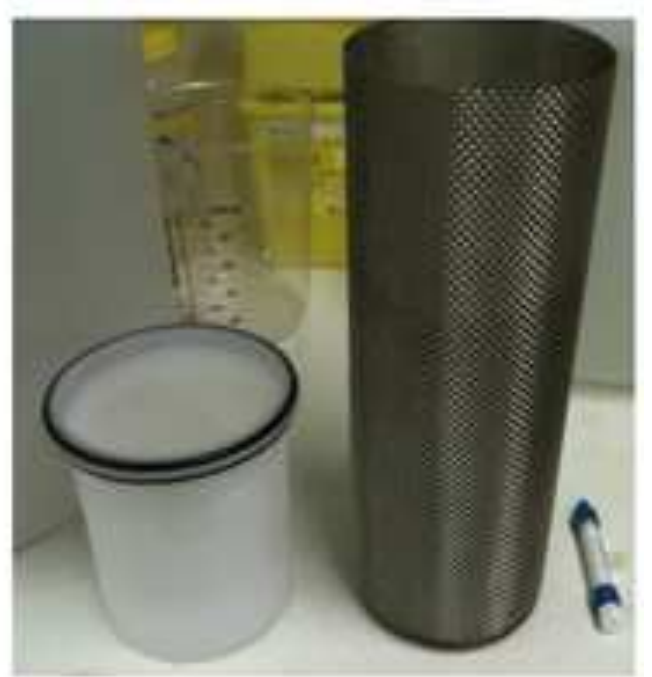

Three stage filtering:

$2 \mathrm{~mm}$ plastic bulk trap filter $40 \mu \mathrm{m}$ stainless steel filter $200 \mathrm{~nm}$ celltrap filter 

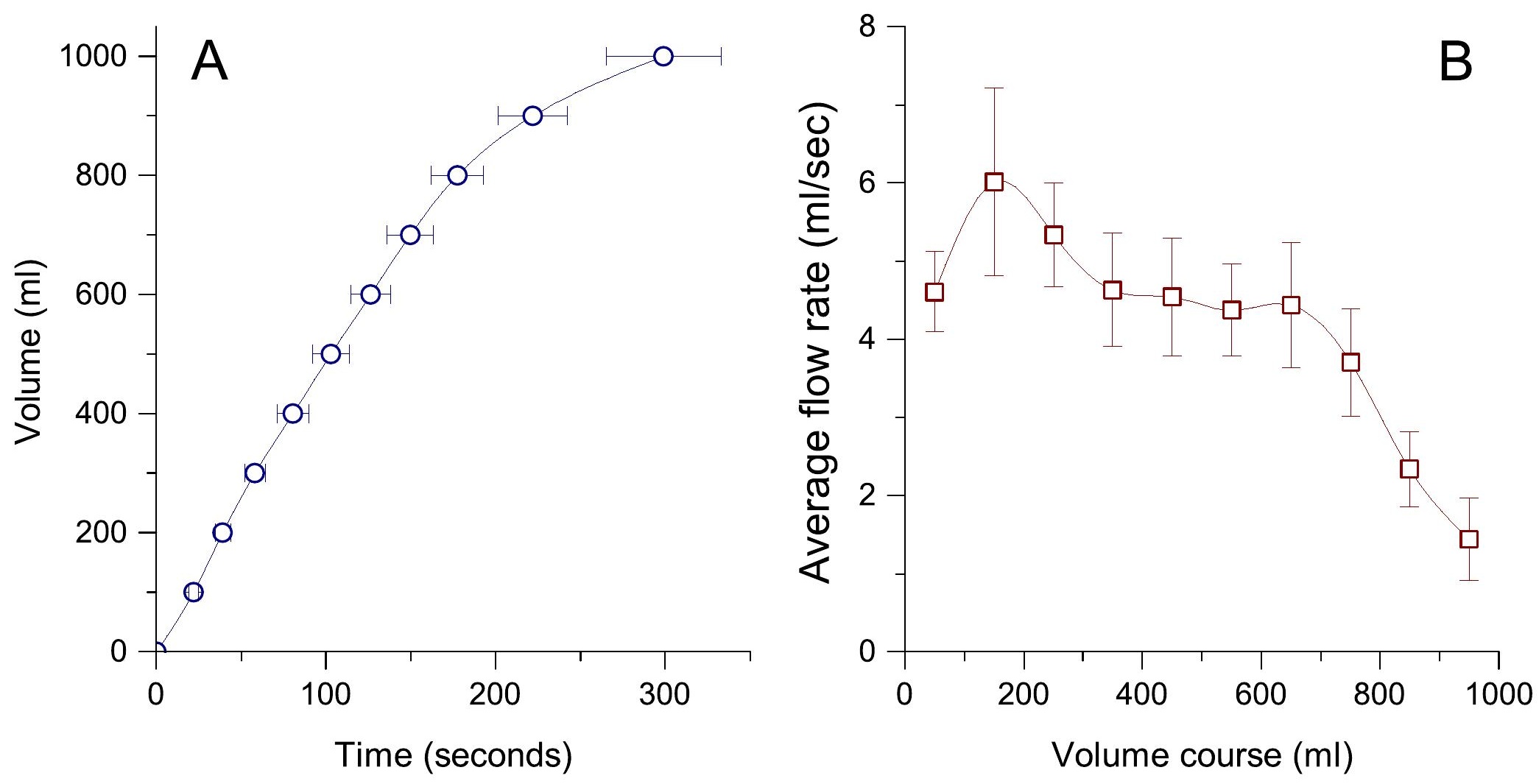


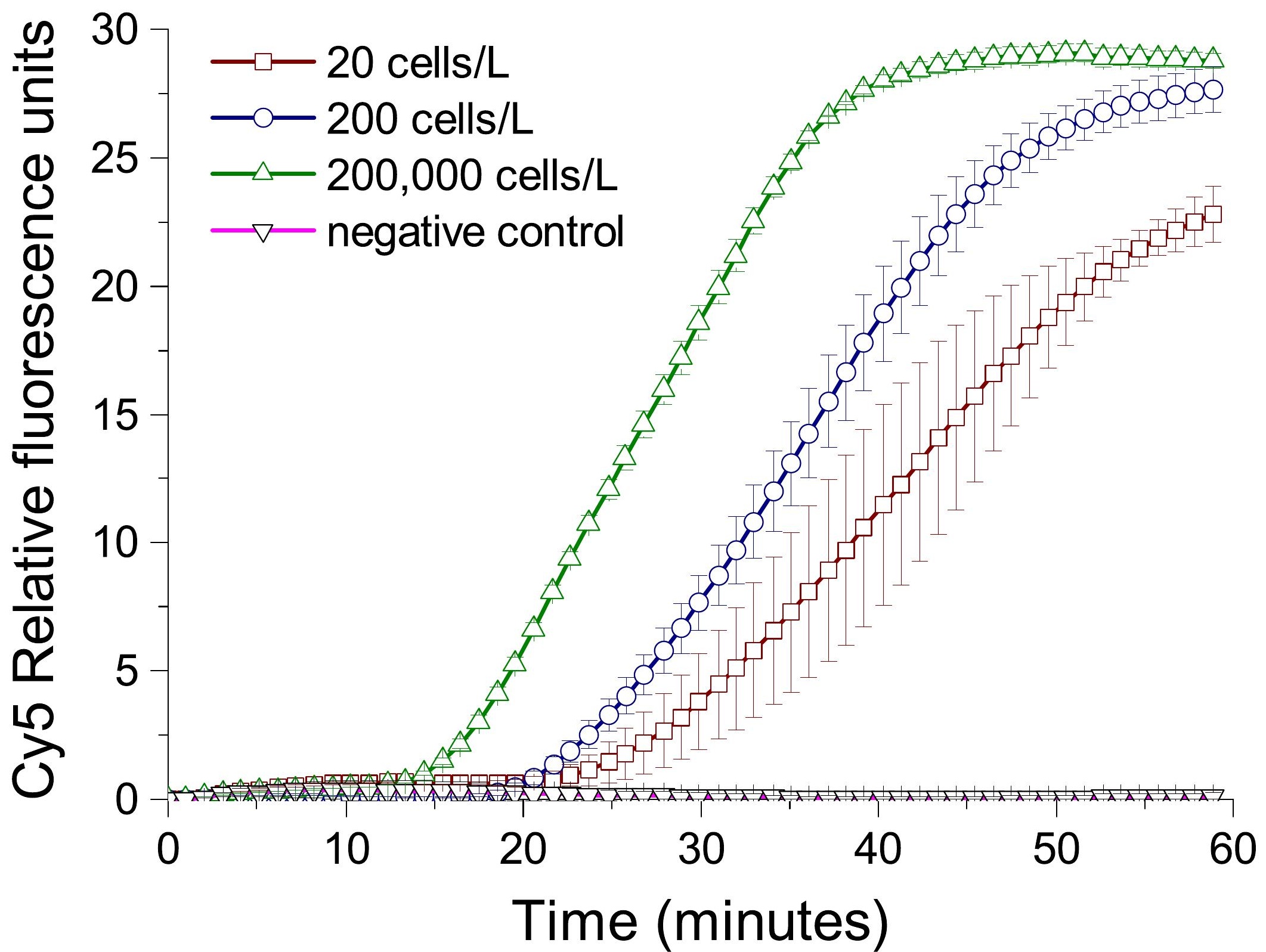




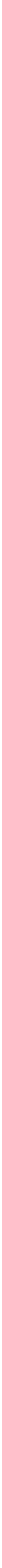


Figure

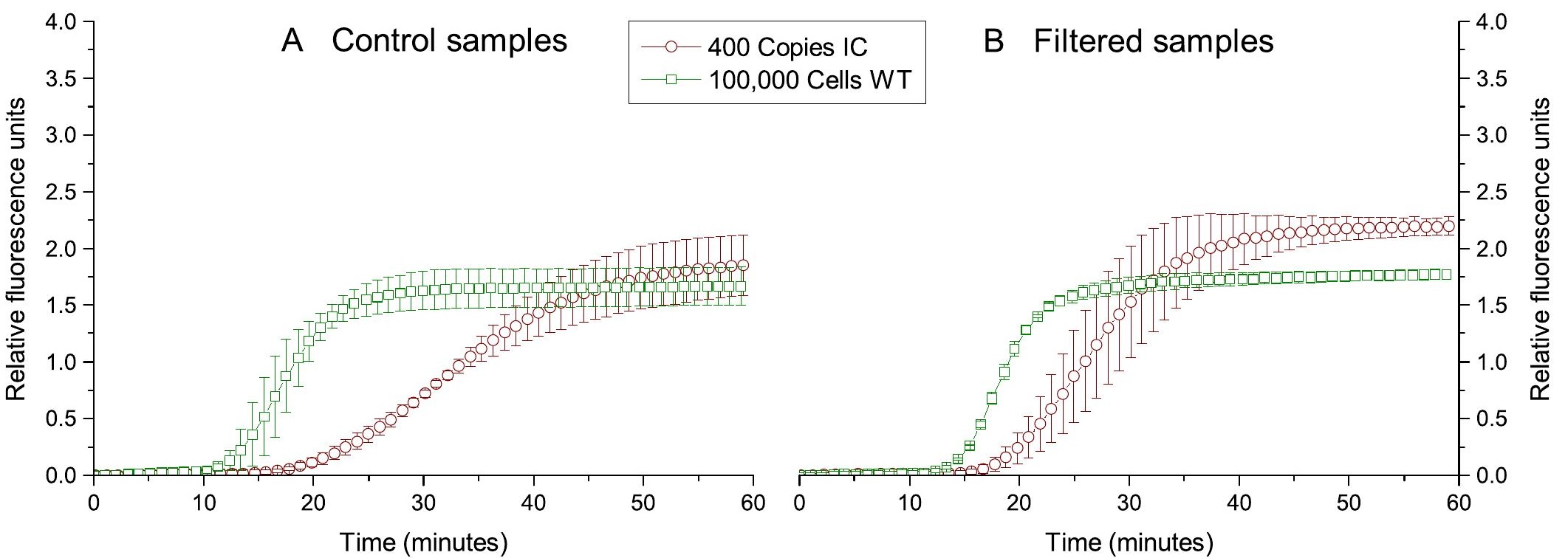



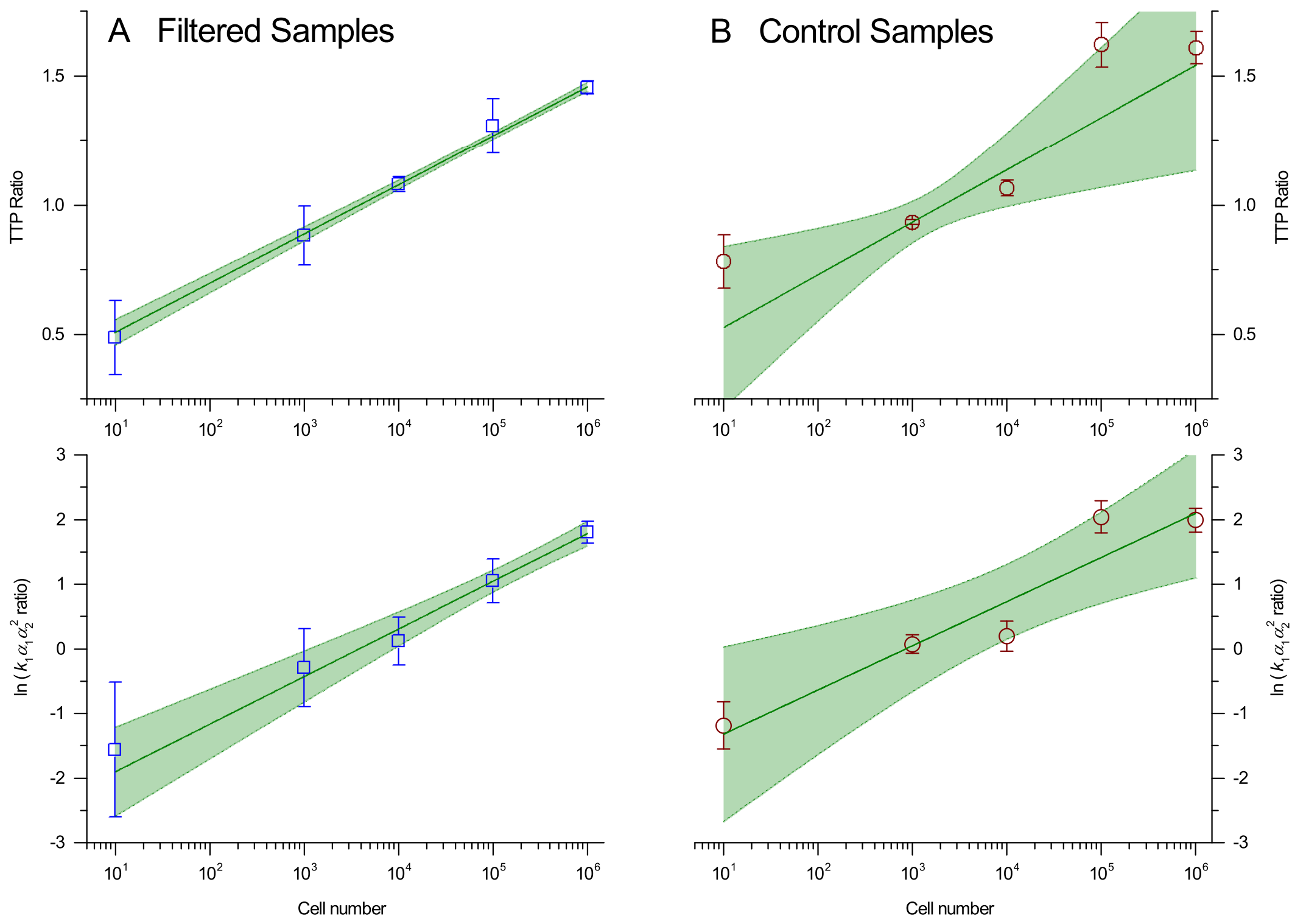


\begin{tabular}{|c|c|}
\hline T. suecica & Sequence (5' to $\left.3^{\prime}\right)$ \\
\hline Forward Primer & ACTGGCTTCAAAGCTGGTGT \\
\hline Reverse Primer & AATTCTAATACGACTCACTATAGGGAGAAGTCCGTCCATACAGTTGTCCA \\
\hline Molecular Beacon & [CY5]- GAGTCGAGATTACCAAGTAAAAGATACTGACCGACTC -[ECLIPSE] \\
\hline Target Sequence & $\begin{array}{l}\text { ACTGGCTTCAAAGCTGGTGT AAAAGACTACCGTTTAACTTACTACACTCC- } \\
\text { AGATTACCAAGTAAAAGATACTGACATTCT TGCAGCATTCCGTTGTAACCCTCAACCAGGTGTTCCACCTG- } \\
\text { AAGAGTGTGGTGCAGCTGTAGCCGCTGAGTCATCAACTGGTACTT GGACAACTGTATGGACGGA }\end{array}$ \\
\hline K. brevis & Sequence (5' to $\left.3^{\prime}\right)$ \\
\hline Forward Primer & ACGTTATTGGGTCTGTGTA \\
\hline Reverse Primer & AATTCTAATACGACTCACTATAGGGAGA AGGTACACACTTTCGTAAACTA \\
\hline Molecular Beacon & [AF488]-GAGTCGCTTAGTCTCGGGTTATTTTTTCGACTC-[BHQ1] \\
\hline Target Sequence & $\begin{array}{l}\text { GAAACGTTATTGGGTCTGTGTACACGAATTAACCTTAGTCTCGGGTTATTTTTTGGACAAGAATGGGC- } \\
\text { TAGTTTACGAAAGTGTGTACCT }\end{array}$ \\
\hline Internal Control & Sequence (5' to $\left.3^{\prime}\right)$ \\
\hline Molecular Beacon & [CY5]-ACGGAGTGGCTGCTTATGGTGACAATCTCCGC-[BHQ2] \\
\hline Sequence & $\begin{array}{l}\text { GAAACGTTATTGGGTCTGTGTACACGAATTAACTGGCTGCTTATGGTGACAATGGACAAGAATGGGC- } \\
\text { TAGTTTACGAAAGTGTGTACCT }\end{array}$ \\
\hline
\end{tabular}

Table 1. List of the sequences of $T$. suecica primers, beacons, and RNA (designed for the purpose of this study); the sequences of $K$. brevis and Internal Control (IC) primers, beacons, and RNA modified from (Tsaloglou et al., 2013). Bold underlined text indicates primer binding sites. 


\begin{tabular}{|c|c|c|c|c|c|c|c|c|}
\hline & \multicolumn{4}{|c|}{ Filtered samples - graphs (a) in Figure 6} & \multicolumn{4}{|c|}{ Control samples - graphs (b) in Figure 6} \\
\hline & \multicolumn{2}{|l|}{ TTP } & \multicolumn{2}{|c|}{ QvariableRatio } & \multicolumn{2}{|l|}{ TTP } & \multicolumn{2}{|c|}{ QvariableRatio } \\
\hline $\begin{array}{l}\text { Pearson's } \\
r\end{array}$ & 0.9994 & & 0.9936 & & 0.9357 & & 0.9515 & \\
\hline \multirow[t]{2}{*}{$\begin{array}{l}\text { Adj. } \quad \text { R- } \\
\text { Square }\end{array}$} & \multicolumn{2}{|c|}{0.9985} & \multicolumn{2}{|l|}{0.9830} & \multicolumn{2}{|c|}{0.8341} & \multicolumn{2}{|l|}{0.8739} \\
\hline & Value & $\begin{array}{l}\text { Standard } \\
\text { error }\end{array}$ & Value & $\begin{array}{l}\text { Standard } \\
\text { error }\end{array}$ & Value & $\begin{array}{l}\text { Standard } \\
\text { error }\end{array}$ & Value & $\begin{array}{l}\text { Standard } \\
\text { error }\end{array}$ \\
\hline $\begin{array}{l}\text { Intercept } \\
\text { (c) }\end{array}$ & 0.317 & 0.0190 & -2.640 & 0.263 & 0.324 & 0.142 & -2.006 & 0.542 \\
\hline Slope (m) & 0.190 & 0.0037 & 0.737 & 0.0483 & 0.203 & 0.0443 & 0.683 & 0.128 \\
\hline
\end{tabular}

Table 2. List of curve matching parameters from the analysis presented in Fig 6 . In each case, the matching parameters are based on the linear equation $y=c+m^{*} x$. 


\title{
SUPPLEMENTARY INFORMATION FOR: A novel portable filtration system for sampling and concentration of micro-organisms: demonstration on marine microalgae with subsequent quantification using IC-NASBA
}

\author{
Christos-Moritz Loukas $^{\mathrm{a}, \mathrm{b}}$, Matthew C. Mowlem ${ }^{\mathrm{a}}$, Maria-Nefeli Tsaloglou ${ }^{\mathrm{a}, \mathrm{b}, \mathrm{c}}$ and Nicolas G. Green $^{\mathrm{c}, \mathrm{d}} *$ \\ a. National Oceanography Centre (NOC), University of Southampton Waterfront Campus, European Way, Southampton, SO14 3ZH, United Kingdom. \\ b. Department of Ocean and Earth Science, University of Southampton Waterfront Campus, European Way, Southampton, SO14 3ZH, United Kingdom. \\ c. Institute for Life Sciences, University of Southampton Highfield Campus, Highfield, Southampton, SO17 1BJ, United Kingdom. \\ d.Department of Electronics and Computer Science (ECS), University of Southampton Highfield Campus, Highfield, Southampton, SO17 1BJ, United \\ Kingdom.
}

This Supplementary document contains the complete set of experimental graphs for section "Quantitative measurement: Karenia brevis" as well as the fitting parameters obtained for all data. A single example is given in the main text.

As an additional piece of information for the Materials and Methods, a permanent archived web link (from the Internet Archive) for the manual of the Hozelock 12L Pressure Sprayer Plus: 4712 (used to build the filter system) is given below:

http://web.archive.org/web/20170206163505/http://www.hozelock.com/wp-content/uploads/2015/05/4712-4716Plus-33885-000-Plus1216L-INTL.pdf

\section{Introduction}

Presented in this document are the results of NASBA on filtered $K$. brevis samples. Wild-type curves experienced an increase in fluorescence at approximately nine minutes before IC curves at $10^{6} \mathrm{cells} / \mathrm{L}$. The temporal gap decreased as cell concentration decreased, until at $10^{4}$ cells/L amplification occurred at the same time. At lower 
concentrations, the wild-type and IC curve relationship was reversed, and the former became less prominent. Wildtype overall signal was at its lowest for the 10 cells/L samples and never surpassed 0.42 RFUs. Control samples followed a similar trend, however wild-type curve signal appeared to be stronger compared to filtered equivalents excluding control samples for $10^{4}$ cells/L and $10^{3}$ cells/L.

For instance, when plotting the IC-NASBA results of samples containing $10^{5}$ cells (Figure 5) it is apparent that the slope difference between WT-RNA and IC-RNA amplification is greater for the control. The filtered replicates show IC amplification approximately seven minutes after WT amplification, and IC maximum fluorescence is reached 15-20 minutes after the WT equivalent. In comparison, control replicates experience an amplification lag which is less than five minutes, and IC reaches maximum fluorescence 10-15 minutes after the WT.

Initial NASBA results are indicative of a trend, where the relationship between wild-type and IC curves may reflect $K$. brevis concentration in filtered samples. Control samples agreed with the observed trend. However they suggest that our sample collection system may not be as effective in preserving target RNA material as traditional laboratory extraction methods. 


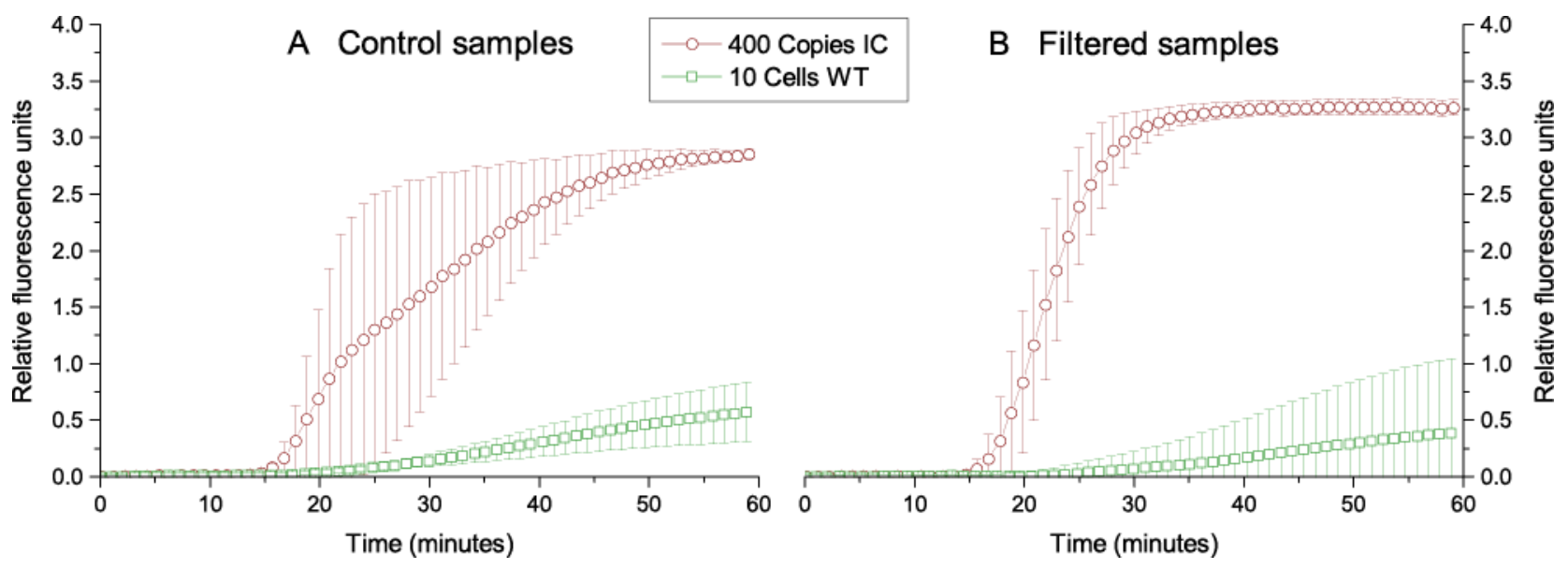

Fig S1 IC-NASBA results for 10 cell equivalents of $K$. brevis with 400 IC copies. The y-axis represents relative fluorescence units, as measured by the EasyQ benchtop incubator, and the x-axis represents time in minutes. WT-RNA amplification is shown as red squares and IC-RNA amplification is shown as green circles. Control samples are illustrated on the left whereas filtered samples are shown on the right. Error bars denote one standard deviation of triplicate samples.

\begin{tabular}{|c|c|c|c|c|c|c|c|c|}
\hline \multirow{2}{*}{\multicolumn{2}{|c|}{$\begin{array}{c}\text { Samples: } \\
\text { (10 cells } 400 \text { IC) }\end{array}$}} & \multicolumn{6}{|c|}{ Parameters } & \multirow{3}{*}{$\ln \left(k_{1} \alpha_{1} \alpha_{2}^{2}\right.$ ratio $)$} \\
\hline & & \multirow{2}{*}{$\frac{\lambda}{6.26}$} & \multirow{2}{*}{$\frac{\alpha_{2}}{0.406}$} & \multirow{2}{*}{$\frac{\alpha_{3}}{10.00}$} & \multirow{2}{*}{$\begin{array}{c}k_{l} \alpha_{1} \\
0.0119\end{array}$} & \multirow{2}{*}{$\begin{array}{c}Y_{0} \\
0.631\end{array}$} & \multirow{2}{*}{$\begin{array}{l}k_{1} \alpha_{1} \alpha_{2}^{2} \\
0.00197\end{array}$} & \\
\hline Filtered & IC & & & & & & & \\
\hline sample 1 & WT & 2.98 & 0.281 & 9.999 & 0.00912 & 0.655 & 0.000721 & \\
\hline \multirow{2}{*}{$\begin{array}{c}\text { Filtered } \\
\text { sample } 2\end{array}$} & IC & 5.84 & 0.493 & 10.00 & 0.0138 & 0.636 & 0.00335 & \multirow{2}{*}{-0.907} \\
\hline & WT & 1.52 & 0.157 & 9.999 & 0.0546 & 0.64 & 0.00135 & \\
\hline \multirow{2}{*}{$\begin{array}{c}\text { Filtered } \\
\text { sample } 3\end{array}$} & IC & 6.24 & 1.283 & 10.00 & 0.0111 & 0.566 & 0.0182 & \multirow{2}{*}{-2.76} \\
\hline & WT & 2.61 & 0.449 & 9.999 & 0.00572 & 0.615 & 0.00115 & \\
\hline \multirow{2}{*}{$\begin{array}{c}\text { Control } \\
\text { sample } 1\end{array}$} & IC & 5940 & 1.392 & 10.00 & 0.0111 & 0.000425 & 0.0215 & \multirow{2}{*}{-0.828} \\
\hline & WT & 10340 & 1.663 & 10.00 & 0.00339 & 0.000148 & 0.009384 & \\
\hline \multirow{2}{*}{$\begin{array}{c}\text { Control } \\
\text { sample } 2\end{array}$} & IC & 8664 & 1.801 & 9.999 & 0.00365 & 0.000292 & 0.0118 & \multirow{2}{*}{-1.18} \\
\hline & WT & 3972 & 0.548 & 9.46 & 0.0121 & 0.000361 & 0.00364 & \\
\hline \multirow{2}{*}{$\begin{array}{c}\text { Control } \\
\text { sample } 3\end{array}$} & IC & 15860 & 2.114 & 9.999 & 0.0016 & 0.000142 & 0.00717 & \multirow{2}{*}{-1.56} \\
\hline & WT & 3765 & 0.761 & 7.49 & 0.00261 & 0.000294 & 0.00151 & \\
\hline
\end{tabular}

Table S1 Fitting parameters from MATLAB curve fitting tool for the IC-NASBA curves, for the 10 cells per litre samples shown in figure S1. 


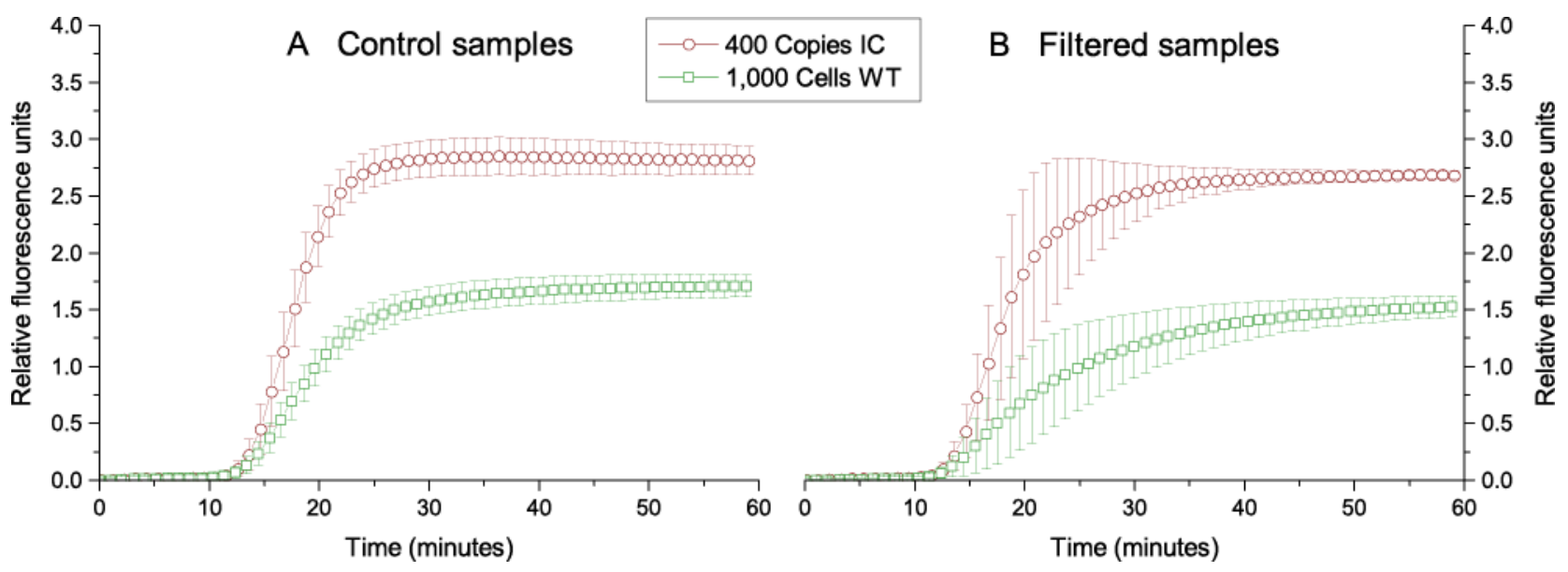

Fig S2 IC-NASBA results for 1000 cell equivalents of $K$. brevis with 400 IC copies. The y-axis represents relative fluorescence units, as measured by the EasyQ benchtop incubator, and the x-axis represents time in minutes. WT-RNA amplification is shown as red squares and IC-RNA amplification is shown as green circles. Control samples are illustrated on the left whereas filtered samples are shown on the right. Error bars denote one standard deviation of triplicate samples.

\begin{tabular}{|c|c|c|c|c|c|c|c|c|}
\hline \multirow{2}{*}{\multicolumn{2}{|c|}{$\begin{array}{c}\text { Samples: } \\
\left(10^{3} \text { cells } 400 \text { IC }\right)\end{array}$}} & \multicolumn{6}{|c|}{ Parameters } & \multirow{2}{*}{$\ln \left(k_{1} \alpha_{1} \alpha_{2}^{2}\right.$ ratio $)$} \\
\hline & & \multirow{2}{*}{$\frac{\lambda}{282}$} & \multirow{2}{*}{$\begin{array}{c}\alpha_{2} \\
0.499\end{array}$} & \multirow{2}{*}{$\begin{array}{c}\alpha_{3} \\
6.30\end{array}$} & \multirow{2}{*}{$\begin{array}{c}k_{l} \alpha_{l} \\
0.0235\end{array}$} & \multirow{2}{*}{$\frac{Y_{0}}{0.00945}$} & \multirow{2}{*}{$\begin{array}{l}k_{1} \alpha_{1} \alpha_{2}^{2} \\
0.00587\end{array}$} & \\
\hline Filtered & IC & & & & & & & \\
\hline sample 1 & WT & 453 & 0.221 & 8.03 & 0.131 & 0.00318 & 0.00640 & 0.0000 \\
\hline \multirow{2}{*}{$\begin{array}{c}\text { Filtered } \\
\text { sample } 2\end{array}$} & IC & 369 & 0.707 & 6.31 & 0.031 & 0.00734 & 0.0153 & \multirow{2}{*}{0.0303} \\
\hline & WT & 176 & 1.16 & 7.78 & 0.0117 & 0.00898 & 0.0158 & \\
\hline \multirow{2}{*}{$\begin{array}{l}\text { Filtered } \\
\text { sample } 3\end{array}$} & IC & 365 & 0.585 & 6.11 & 0.0373 & 0.00746 & 0.0127 & \multirow{2}{*}{-0.984} \\
\hline & WT & 44.0 & 0.940 & 9.24 & 0.00541 & 0.0323 & 0.00477 & \\
\hline \multirow{2}{*}{$\begin{array}{l}\text { Control } \\
\text { sample } 1\end{array}$} & IC & 360 & 0.546 & 5.97 & 0.0369 & 0.00816 & 0.0110 & \multirow{2}{*}{0.142} \\
\hline & WT & 287 & 0.877 & 8.44 & 0.0165 & 0.00597 & 0.0127 & \\
\hline \multirow{2}{*}{$\begin{array}{l}\text { Control } \\
\text { sample } 2\end{array}$} & IC & 349 & 0.638 & 6.25 & 0.0364 & 0.00844 & 0.0148 & \multirow{2}{*}{-0.0911} \\
\hline & WT & 410 & 0.256 & 8.07 & 0.206 & 0.00427 & 0.0135 & \\
\hline \multirow{2}{*}{$\begin{array}{l}\text { Control } \\
\text { sample } 3\end{array}$} & IC & 375 & 0.553 & 6.09 & 0.0376 & 375 & 0.0115 & \multirow{2}{*}{0.163} \\
\hline & WT & 61.1 & 1.34 & 9.29 & 0.00755 & 0.0258 & 0.0135 & \\
\hline
\end{tabular}

Table S2 Fitting parameters from MATLAB curve fitting tool for the IC-NASBA curves for the 1000 cells per litre samples shown in figure S2 


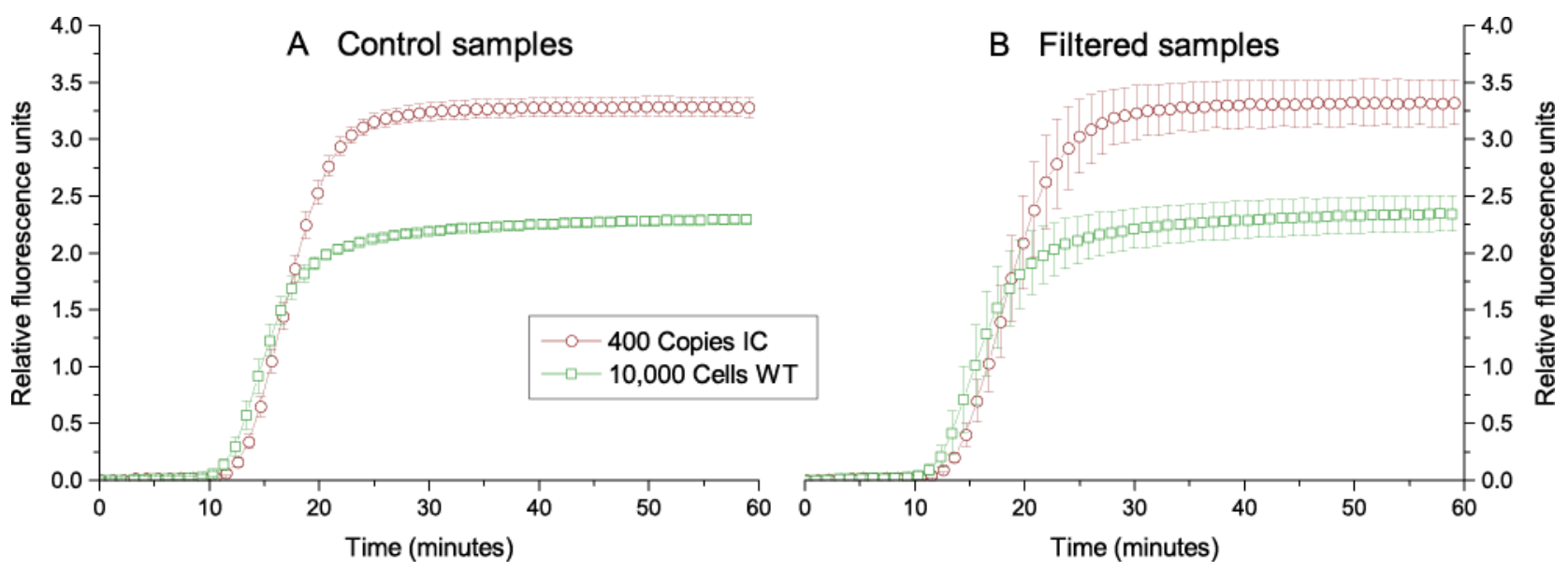

Fig S3 IC-NASBA results for $10^{4}$ cell equivalents of $K$. brevis with 400 IC copies. The y-axis represents relative fluorescence units, as measured by the EasyQ benchtop incubator, and the x-axis represents time in minutes. WT-RNA amplification is shown as red squares and IC-RNA amplification is shown as green circles. Control samples are illustrated on the left whereas filtered samples are shown on the right. Error bars denote one standard deviation of triplicate samples.

\begin{tabular}{|c|c|c|c|c|c|c|c|c|}
\hline \multirow{2}{*}{\multicolumn{2}{|c|}{$\begin{array}{c}\text { Samples: } \\
\left(10^{4} \text { cells } 400 \text { IC }\right)\end{array}$}} & \multicolumn{6}{|c|}{ Parameters } & \multirow{2}{*}{$\ln \left(k_{1} \alpha_{1} \alpha_{2}^{2}\right.$ ratio $)$} \\
\hline & & \multirow{2}{*}{$\begin{array}{c}\lambda \\
405\end{array}$} & \multirow{2}{*}{$\begin{array}{c}\alpha_{2} \\
0.518\end{array}$} & \multirow{2}{*}{$\begin{array}{c}\alpha_{3} \\
5.31\end{array}$} & \multirow{2}{*}{$\begin{array}{c}k_{1} \alpha_{1} \\
0.0386\end{array}$} & \multirow{2}{*}{$\begin{array}{c}Y_{0} \\
0.00819\end{array}$} & \multirow{2}{*}{$\begin{array}{l}k_{1} \alpha_{1} \alpha_{2}^{2} \\
0.0104\end{array}$} & \\
\hline Filtered & IC & & & & & & & \\
\hline sample 1 & WT & 380 & 0.678 & 5.53 & 0.0357 & 0.00608 & 0.0164 & 0.700 \\
\hline \multirow{2}{*}{$\begin{array}{l}\text { Filtered } \\
\text { sample } 2\end{array}$} & IC & 364 & 0.504 & 5.73 & 0.0373 & 0.00608 & 0.00949 & \multirow{2}{*}{0.171} \\
\hline & WT & 382 & 0.555 & 5.08 & 0.0366 & 0.00639 & 0.0113 & \\
\hline \multirow{2}{*}{$\begin{array}{l}\text { Filtered } \\
\text { sample } 3\end{array}$} & IC & 278 & 0.736 & 8.40 & 0.0219 & 0.0114 & 0.0119 & \multirow{2}{*}{-0.266} \\
\hline & WT & 350 & 0.593 & 5.15 & 0.0259 & 0.00628 & 0.00911 & \\
\hline \multirow{2}{*}{$\begin{array}{l}\text { Control } \\
\text { sample } 1\end{array}$} & IC & 322 & 0.734 & 6.71 & 0.0266 & 0.0105 & 0.0143 & \multirow{2}{*}{-0.0712} \\
\hline & WT & 289 & 0.757 & 5.50 & 0.0233 & 0.00789 & 0.0134 & \\
\hline \multirow{2}{*}{$\begin{array}{l}\text { Control } \\
\text { sample } 2\end{array}$} & IC & 386 & 0.579 & 5.84 & 0.0376 & 0.00846 & 0.0126 & \multirow{2}{*}{0.345} \\
\hline & WT & 333 & 0.761 & 5.75 & 0.0306 & 0.00680 & 0.0178 & \\
\hline \multirow{2}{*}{$\begin{array}{l}\text { Control } \\
\text { sample } 3\end{array}$} & IC & 520 & 0.538 & 5.30 & 0.0366 & 0.00632 & 0.0106 & \multirow{2}{*}{0.321} \\
\hline & WT & 408 & 0.663 & 5.51 & 0.0332 & 0.00551 & 0.0146 & \\
\hline
\end{tabular}

Table S3 Fitting parameters from MATLAB curve fitting tool for the IC-NASBA curves, for the $10^{4}$ cells per litre samples shown in figure S3 


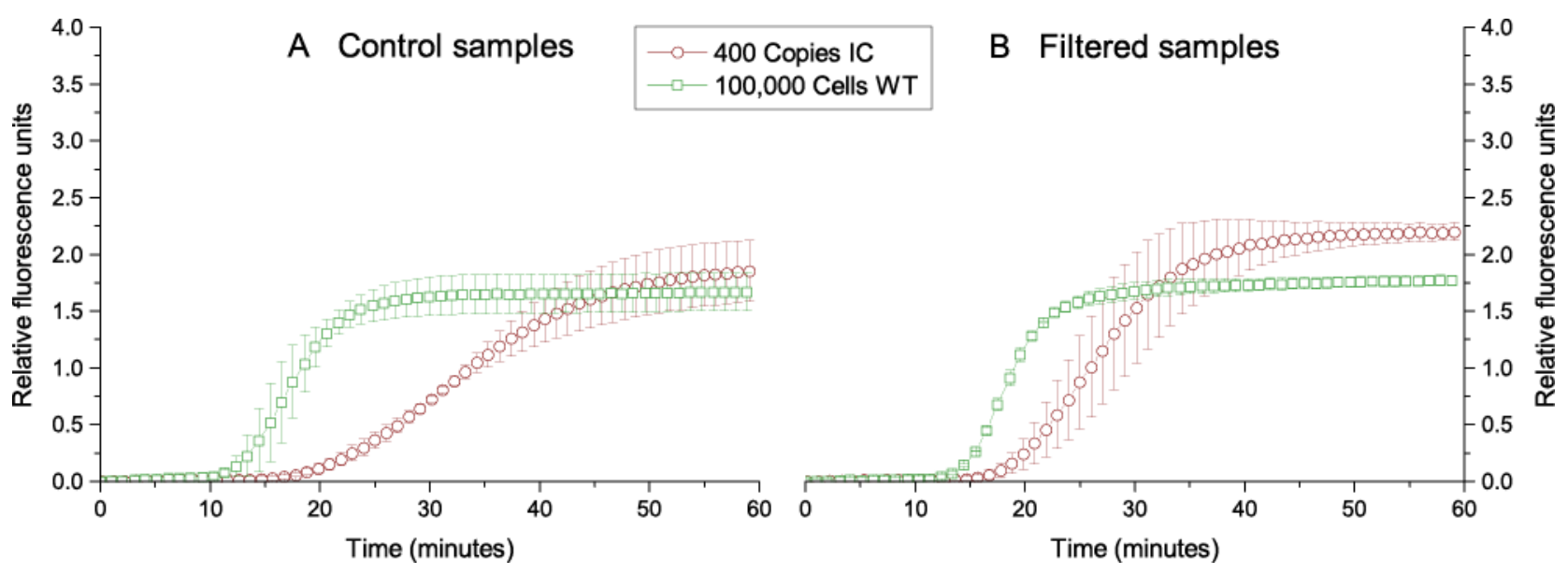

Fig S4 IC-NASBA results for $10^{5}$ cell equivalents of $K$. brevis with 400 IC copies. The y-axis represents relative fluorescence units, as measured by the EasyQ benchtop incubator, and the x-axis represents time in minutes. WT-RNA amplification is shown as red squares and IC-RNA amplification is shown as green circles. Control samples are illustrated on the left whereas filtered samples are shown on the right. Error bars denote one standard deviation of triplicate samples.

\begin{tabular}{|c|c|c|c|c|c|c|c|c|}
\hline \multirow{2}{*}{\multicolumn{2}{|c|}{$\begin{array}{c}\text { Samples: } \\
\left(10^{5} \text { cells } 400 \text { IC }\right)\end{array}$}} & \multicolumn{6}{|c|}{ Parameters } & \multirow{2}{*}{$\ln \left(k_{1} \alpha_{1} \alpha_{2}^{2}\right.$ ratio $)$} \\
\hline & & \multirow{2}{*}{$\begin{array}{c}\lambda \\
182\end{array}$} & \multirow{2}{*}{$\begin{array}{c}\alpha_{2} \\
0.461\end{array}$} & \multirow{2}{*}{$\begin{array}{c}\alpha_{3} \\
9.64\end{array}$} & \multirow{2}{*}{$\begin{array}{c}k_{1} \alpha_{1} \\
0.0144\end{array}$} & \multirow{2}{*}{$\begin{array}{c}Y_{0} \\
0.0124\end{array}$} & \multirow{2}{*}{$\begin{array}{l}k_{1} \alpha_{1} \alpha_{2}^{2} \\
0.00307\end{array}$} & \\
\hline Filtered & IC & & & & & & & \\
\hline sample 1 & WT & 590 & 0.236 & 6.13 & 0.180 & 0.00291 & 0.010 & 1.10 \\
\hline \multirow{2}{*}{$\begin{array}{l}\text { Filtered } \\
\text { sample } 2\end{array}$} & IC & 457 & 0.323 & 6.47 & 0.0349 & 0.00513 & 0.00365 & \multirow{2}{*}{1.31} \\
\hline & WT & 332 & 0.716 & 8.27 & 0.0263 & 0.00542 & 0.0135 & \\
\hline \multirow{2}{*}{$\begin{array}{l}\text { Filtered } \\
\text { sample } 3\end{array}$} & IC & 320 & 0.558 & 8.68 & 0.0209 & 0.00708 & 0.0065 & \multirow{2}{*}{0.667} \\
\hline & WT & 259 & 0.772 & 7.88 & 0.0212 & 0.00672 & 0.0127 & \\
\hline \multirow{2}{*}{$\begin{array}{l}\text { Control } \\
\text { sample } 1\end{array}$} & IC & 747 & 0.284 & 7.86 & 0.0222 & 0.00313 & 0.0018 & \multirow{2}{*}{2.30} \\
\hline & WT & 251 & 1.018 & 9.32 & 0.0173 & 0.00721 & 0.0179 & \\
\hline \multirow{2}{*}{$\begin{array}{l}\text { Control } \\
\text { sample } 2\end{array}$} & IC & 499 & 0.316 & 7.93 & 0.0209 & 0.00429 & 0.00209 & \multirow{2}{*}{1.80} \\
\hline & WT & 170 & 0.737 & 7.83 & 0.0234 & 0.00963 & 0.0127 & \\
\hline \multirow{2}{*}{$\begin{array}{l}\text { Control } \\
\text { sample } 3\end{array}$} & IC & 650 & 0.356 & 6.04 & 0.0169 & 0.00257 & 0.00215 & \multirow{2}{*}{2.02} \\
\hline & WT & 463 & 0.234 & 5.22 & 0.297 & 0.00334 & 0.0162 & \\
\hline
\end{tabular}

Table S4 Fitting parameters from MATLAB curve fitting tool for the IC-NASBA curves, for the $10^{5}$ cells per litre samples shown in figure S4 


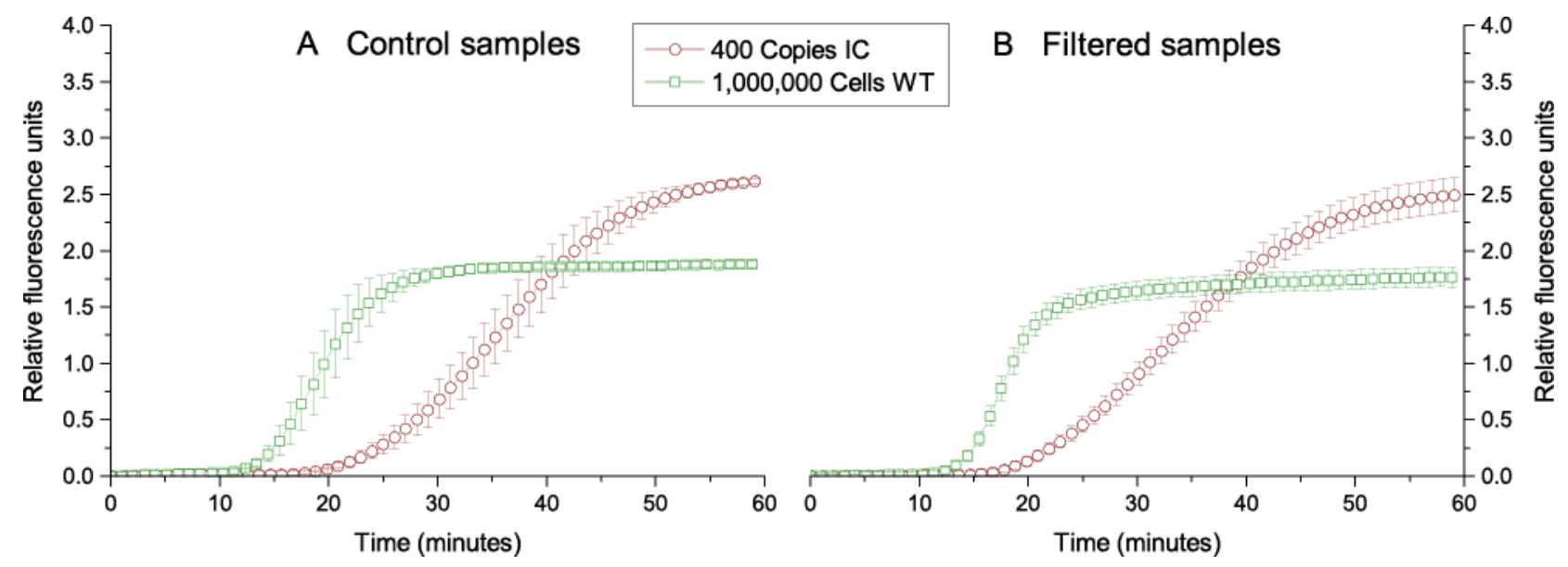

Fig S5 IC-NASBA results for $10^{6}$ cell equivalents of $K$. brevis with 400 IC copies. The y-axis represents relative fluorescence units, as measured by the EasyQ benchtop incubator, and the x-axis represents time in minutes. WT-RNA amplification is shown as red squares and IC-RNA amplification is shown as green circles. Control samples are illustrated on the left whereas filtered samples are shown on the right. Error bars denote one standard deviation of triplicate samples.

\begin{tabular}{|c|c|c|c|c|c|c|c|c|}
\hline \multirow{2}{*}{\multicolumn{2}{|c|}{$\begin{array}{c}\text { Samples: } \\
\left(10^{6} \text { cells } 400 \text { IC }\right)\end{array}$}} & \multicolumn{6}{|c|}{ Parameters } & \multirow{2}{*}{$\ln \left(k_{1} \alpha_{1} \alpha_{2}^{2}\right.$ ratio $)$} \\
\hline & & \multirow{2}{*}{$\begin{array}{c}\lambda \\
729\end{array}$} & \multirow{2}{*}{$\begin{array}{c}\alpha_{2} \\
0.321\end{array}$} & \multirow{2}{*}{$\begin{array}{c}\alpha_{3} \\
7.75\end{array}$} & \multirow{2}{*}{$\begin{array}{c}k_{1} \alpha_{l} \\
0.0157\end{array}$} & \multirow{2}{*}{$\begin{array}{c}Y_{0} \\
0.00430\end{array}$} & \multirow{2}{*}{$\begin{array}{l}k_{1} \alpha_{1} \alpha_{2}^{2} \\
0.00162\end{array}$} & \\
\hline Filtered & IC & & & & & & & 160 \\
\hline sample 1 & WT & 522 & 0.455 & 4.37 & 0.0393 & 0.00350 & 0.00815 & 1.02 \\
\hline \multirow{2}{*}{$\begin{array}{l}\text { Filtered } \\
\text { sample } 2\end{array}$} & IC & 1180 & 0.252 & 5.41 & 0.0266 & 0.00240 & 0.00168 & \multirow{2}{*}{1.94} \\
\hline & WT & 348 & 0.618 & 6.73 & 0.0306 & 0.00488 & 0.0117 & \\
\hline \multirow{2}{*}{$\begin{array}{l}\text { Filtered } \\
\text { sample } 3\end{array}$} & IC & 1988 & 0.312 & 7.99 & 0.0152 & 0.00148 & 0.00148 & \multirow{2}{*}{1.85} \\
\hline & WT & 333 & 0.560 & 5.96 & 0.0297 & 0.00511 & 0.00940 & \\
\hline \multirow{2}{*}{$\begin{array}{l}\text { Control } \\
\text { sample } 1\end{array}$} & IC & 101 & 0.380 & 9.36 & 0.0135 & 0.0308 & 0.00194 & \multirow{2}{*}{1.82} \\
\hline & WT & 452 & 0.660 & 7.14 & 0.0274 & 0.00419 & 0.0119 & \\
\hline \multirow{2}{*}{$\begin{array}{l}\text { Control } \\
\text { sample } 2\end{array}$} & IC & 1322 & 0.277 & 8.58 & 0.0164 & 0.00270 & 0.00125 & \multirow{2}{*}{2.19} \\
\hline & WT & 440 & 0.561 & 6.78 & 0.0355 & 0.00438 & 0.0112 & \\
\hline \multirow{2}{*}{$\begin{array}{c}\text { Control } \\
\text { sample } 3\end{array}$} & IC & 1115 & 0.309 & 9.60 & 0.0118 & 0.00324 & 0.00113 & \multirow{2}{*}{1.967} \\
\hline & WT & 354 & 0.551 & 7.75 & 0.0266 & 0.00518 & 0.00807 & \\
\hline
\end{tabular}

Table S5 Fitting parameters from MATLAB curve fitting tool for the IC-NASBA curves, for the $10^{6}$ cells per litre samples shown in figure S5 


\section{HARMFUL ALGAE}

\section{AUTHOR DECLARATION}

Submission of an article implies that the work described has not been published previously (except in the form of an abstract or as part of a published lecture or academic thesis), that it is not under consideration for publication elsewhere, that its publication is approved by all authors and tacitly or explicitly by the responsible authorities where the work was carried out, and that, if accepted, it will not be published elsewhere in the same form, in English or in any other language, without the written consent of the copyright-holder.

By attaching this Declaration to the submission, the corresponding author certifies that:

- The manuscript represents original and valid work and that neither this manuscript nor one with substantially similar content under the same authorship has been published or is being considered for publication elsewhere.

- Every author has agreed to allow the corresponding author to serve as the primary correspondent with the editorial office, and to review the edited typescript and proof.

- Each author has given final approval of the submitted manuscript and order of authors. Any subsequent change to authorship will be approved by all authors.

- Each author has participated sufficiently in the work to take public responsibility for all the content. 